\title{
A desleitura como tática, ou a tática da desleitura: reflexões sobre João Gilberto, Dorival Caymmi e a busca da legitimação de uma identidade artística
}

The Misreading as a Tactic or the Tactic of Misreading: reflections on João Gilberto, Dorival Caymmi and the pursuit of legitimacy of an artistic identity 


\section{Resumo}

Nesse artigo, de caráter musicológico, faremos uma análise comparativa utilizando duas interpretações da música Rosa Morena: uma do seu próprio autor Dorival Caymmi (1914-2008) e outra de João Gilberto (1931-). A partir da utilização do conceito de Campo, definido por Bourdieu (1996; 2013), iremos abordar o cenário em que o disco Chega de Saudade é lançado. Nossa premissa será que Gilberto, ao utilizar a composição Rosa Morena como base para seus procedimentos artísticos específicos, acaba estabelecendo uma desleitura da obra de Caymmi. Identificada como uma ação deformadora, a desleitura seria uma ferramenta de caráter tático, agindo dentro um ambiente de intensos conflitos e responsável por capitalizar bens simbólicos para a Bossa Nova, porém, tal economia acontecerá em uma via dupla: ao mesmo tempo em que se fortalecem as especificidades do novo estilo, a desleitura o enfraquece, devido à conexão que se estabelece com a tradição da música popular que Caymmi representa.

Palavras Chave: João Gilberto; Dorival Caymmi; Identidade; Desleitura; Táticas Simbólicas.

\section{Abstract}

In this article, of a musicology nature, we'll make a comparative analysis using two interpretations of the music Rosa Morena: the first one by his own composer, Dorival Caymmi (1914-2008), and the other one by João Gilberto (1931- ). From the use of the concept of Field, defined by Bordieu (1996;2013), we'll approach the scenery in which the album "Chega de Saudade" is released.Our premise is that Gilberto, when using the song "Rosa Morena" as a base for his specific artistic procedures, establishes a misreading of the Caymmi's work. Identified as a deforming action, the misreading would be a tool of a tactical nature, acting inside an environment of intense conflicts and responsible for capitalize symbolic assets for Bossa Nova, however, such an economy will happen in a double way: in the same time the specificities of the new style becomes stronger, the misreading makes it weaker, due to the conection stablished by the popular music tradition that Caymmi represents.

Keywords: João Gilberto; Dorival Caymmi; Identity; Misreading; Symbolic Tactic. 


\section{INTRODUÇÃO}

O presente artigo é produto das reflexões e conclusões oriundas da análise comparativa de duas interpretações de uma mesma música, Rosa Morena de Dorival Caymmi (1914-2008). A gravação que usamos como referência é a que consta no disco Sambas de Caymmi de 1955, um dos trabalhos mais representativos desse artista. A outra gravação está presente no disco de João Gilberto (1931-) chamado Chega de Saudade, de 1959, considerado o marco zero da Bossa Nova. Acreditamos que a partir de uma análise comparativa amparada por um referencial teórico específico, poderemos apontar questões interessantes sobre a maneira como certos aspectos - que acreditamos fundamentais - dos procedimentos musicais de Gilberto foram organizados a partir de um trabalho de desleitura da obra de Caymmi. Entendemos que esses elementos constituem peças importantes na organização de um quadro mais amplo e que, ao serem problematizados e abordados sob a ótica da desleitura, podem iluminar aspectos extremamente complexos da identidade artística do artista João Gilberto.

Observaremos como certos procedimentos musicais oriundos do fazer artístico de Caymmi foram desleiturizados por Gilberto; com isso, se apresenta a possibilidade de apontar como as interpretações musicais de Gilberto - que em certos aspectos são devedoras das interpretações de Caymmi - serão utilizadas para um determinado propósito dentro de uma economia simbólica. Buscaremos fundamentar duas premissas básicas: a primeira seria a possibilidade de entender a abordagem musical de Gilberto a partir do conceito de desleitura, cujo resultado seria o que entendemos como tática a ser implementada dentro de um espaço simbólico específico. A segunda premissa seria um desdobramento da primeira: acreditamos que essa tática ocasionaria uma extrema dificuldade na busca pelo estabelecimento de uma identidade artística coesa, principalmente devido ao caráter devedor da desleitura empreendida por João Gilberto - é o que chamaremos de óbice identitário.

Os fundamentos teóricos de nossa investigação serão os conceitos de Desleitura, de Bloom (2003), e o de Tática, de Certeau (2013), ambos serão inscritos sob a ótica dos conceitos de campo e estratégia, de Bourdieu (1996; 2013). Nossas análises musicais se basearão em certos aspectos oriundos do paradigma indiciário oriundo da obra de Ginsburg (1983; 1987), já que João Gilberto não deixou testemunhos suficientes para dar conta das questões que serão abordadas aqui e, como ferramenta fundamental nesse ponto do artigo, utilizaremos os pés-métricos gregos que foram extraídos de um texto de Messiaen (1992). Acreditamos que nossa abordagem musicológica poderá apontar questões interessantes sobre um pequeno conjunto de engrenagens que fazem parte do processo de organização de materiais artísticos presentes na música de João Gilberto, personagem fundamental na história da música popular brasileira, além de nos possibilitar esboçar algumas considerações sobre aspectos mais específicos do cenário artístico do Brasil do final da década de 1950 e início de 1960.

Toda obra de arte na realidade pode ser entendida como uma tentativa de afirmação - e porque não legitimação - com relação à outra obra de arte. No caso específico dessa investigação, o autor se torna obcecado não apenas por polir e esmerilhar sua 
própria obra, mas também tenta resolver contradições nas obras de seus predecessores e esse cenário de intensas construções e reformulações se inscreve no interior de uma série de outras disputas simbólicas que potencializam permanentes aporias ${ }^{1}$. Dito isso, mostraremos o contexto em que a obra de João Gilberto surge e ato contínuo, apresentaremos os conceitos de desleitura, estratégia e tática.

Ao indicar um tipo de dinâmica entre os processos de utilizar e o de descartar os materiais artísticos dos artistas que de certa forma estavam presentes no horizonte em torno desse artista forte, o conceito de desleitura contribuirá com o suporte necessário para a análise das complexas manipulações dos elementos artísticos que foram empreendidas por João Gilberto. Embora essas interpretações possam ter se organizado de maneiras extremamente complexas - e provavelmente alguns desses procedimentos desleiturizantes tenham sido empreendidos de maneira inconsciente -, os resultados dessas práticas musicais, ao serem entendidas como bens simbólicos, serão importantes para detectarmos indícios do que seriam as tomadas de posição dentro de um campo.

Iremos apresentar o conceito de estratégia e depois definiremos o que seria a tática. Após esse momento, ambos serão problematizados, já que apresentam certas limitações que inviabilizariam sua utilização de maneira estrita². Ao final desse ponto, iremos defender a utilização do conceito de tática, mas a partir da visão defendida por Pereira e Sarti (2010). Concluiremos essa seção apontando que a desleitura pode ser entendida como tática simbólica, no que poderemos conceituar como um projeto específico de construção de identidade artística.

Assim como os autores citados, defenderemos que existe a interpenetração de elementos estratégicos na tática e vice-versa, com isso, cada um dos conceitos deve ser iluminado pelo outro, numa espécie de dialética. Identificaremos como a desleitura em alguns momentos terá características de tática e em outros apresentará elementos de estratégia. Devido a certas questões que apontaremos mais adiante, as características táticas serão fundamentais na prática desleiturizante, logo, é como tática que entenderemos os procedimentos interpretativos de João Gilberto.

A utilização dos procedimentos desleiturizantes - entendidos como tática simbólica, mas que contém em si características estratégias - seria consequência de questões envolvendo dois níveis do fazer arte: no primeiro, mais particular, ela seria uma resposta organizada à tradição e que, ao ser apresentada pelo artista, contribuiria para a resolução do seu próprio processo de formação identitário. Tal processo se desenrola no

\footnotetext{
1 Ao se fazer uma releitura de uma obra, necessariamente se interpreta sua diferença com relação a outras obras: "uma performance, ainda que original, ganha forma a partir da relação com expectativas estilísticas e contextuais conhecidas. Mesmo que para deturpá-las, baseia-se nelas". (FINNEGAN, 2008, p. 36).

2 No decorrer do texto iremos utilizar os conceitos de Campo e de tomada de posição e o de Tática. Entretanto, iremos problematizar certos aspectos desses conceitos, evocando aqui a questão de que "nenhuma teoria está em concordância com todos os fatos do seu domínio" (Feyerabend apud BARROS, 2013, p. 224). Afirmamos que não é nossa intenção pincelarmos o que nos convêm desses conceitos, empenando o referencial teórico de maneira a podermos utilizá-lo a nosso bel prazer, buscando com isso ostentar certas credenciais teóricas. Como já dissemos, se algo não corresponde a nossas expectativas teóricas, não forçaremos uma correspondência apenas para alcançarmos um determinado fim. Da mesma forma, não iremos confirmar toda uma teoria simplesmente porque uma determinada parte nos interessa. Acreditamos que um quadro conceitual pode ser utilizado com proveito, na verdade, mesmo quando ignoramos ou rejeitamos completamente certas hipóteses gerais, que nas origens, o acompanham (Sobre isso, ver GUSMÃO, 2012).
} 
campo e diante dos agentes do campo - outros artistas, instituições e do público de maneira mais geral. No segundo, de caráter mais amplo, ela, a desleitura tática, se guiará pela necessidade de legitimação do estilo - no caso, a Bossa Nova - dentro de um cenário simbólico extremamente tumultuado e repleto de conflitos.

Após a definição do que entendemos por tática, proporemos que a interpretação de Gilberto - no caso, a da música Rosa Morena - pode ser compreendida como uma ferramenta simbólica de caráter tático. Ela potencializará a posição do artista dentro de um cenário e, ao conectar o intérprete bossa novista a uma tradição dotada de alto capital simbólico, contribuirá de maneira substancial no processo de busca pela legitimação do intérprete e consequentemente do estilo, ambos inseridos em um campo simbólico específico. Esse cenário deve ser entendido como um campo, nos moldes bourdieanos, ou seja, um ambiente de extrema disputa simbólica: por um lado, temos a defesa de um tipo de arte genuinamente nacional, repudiando certos procedimentos artísticos que vinha principalmente dos EUA e valorizando os característicos regionais do que seria entendido como música popular brasileira 3 .

Ao utilizar os procedimentos artísticos de um mestre - no caso, Caymmi - para questionar certos padrões de interpretativos que eram compreendidos como tradicionais, e desleiturizá-lo para assim construir seu próprio fazer artístico, Gilberto de certa forma contribui para conquistar duas coisas: apoio para sua causa e fortalecimento de uma identidade musical genuinamente brasileira. Entretanto, surge o que chamaremos de óbice da identidade, ou seja, a impossibilidade de estabelecer uma identidade coesa e sólida. Queremos dizer que o conceito de identidade

(...) é um "conceito altamente contestado". Sempre que se ouvir essa palavra pode-se estar certo de que está havendo uma batalha. O campo de batalha é o lar natural da identidade. Ela só vem a luz no tumulto da batalha, e dorme e silencia no momento em que desaparecem os ruídos da refrega. (...) A identidade é uma luta simultânea contra a dissolução e a fragmentação; uma intenção de devorar e ao mesmo tempo uma recusa resoluta a ser devorado... (BAUMAN, 2005, p. 84).

A metáfora de um "campo de batalha" nos conduzirá em nossa operacionalização do conceito bourdieano de campo, um espaço de constantes lutas simbólicas. Uma das possibilidades de se definir um tipo de identidade é a partir da negação com relação ao outro, porém, no caso específico da Bossa Nova de João Gilberto, a identidade se organiza de maneira dialética, não apenas pela recusa, mas pela conexão com o outro.

Na seção final de nosso texto, iremos estabelecer uma análise comparativa entre as interpretações musicais de ambos os artistas ${ }^{4}$, porém, devido à extrema complexidade que perpassa toda tentativa de entabular uma comparação entre obras que são oriundas de contextos específicos e direcionadas por motivações artísticas diferentes,

\footnotetext{
3 Por outro lado, temos um tipo de postura onde uma parcela das nossas elites sócio-econômicas e setores da classe média incidiram na cópia de modelos importados e utilizando a Bossa Nova, como a música que uniria a tradição musical brasileira com o que havia de mais avançado na música internacional (BOLLOS, 2010). É nesse clima de tensão, cujas faíscas imprimiam marcas profundas nesse espaço simbólico específico, que surge a tática da desleitura.

4 De acordo com Barros (2014) a comparação possibilita iluminar um objeto ou uma situação a partir de outro, fazendo analogias, buscando semelhanças e diferenças, percebendo tanto as variações como as repetições de um determinado modelo.
} 
evitaremos aplicar uma abordagem que supostamente dê conta de todos os aspectos da obra musical. Com isso, queremos dizer que apontaremos nosso enfoque analítico para um ponto musical específico dessas interpretações e acreditamos que ele será suficiente para fundamentar nossas conclusões e confirmar nossas premissas: iremos analisar das divisões rítmicas e nas acentuações presentes nas interpretações vocais empreendidas em Rosa Morena por Dorival Caymmi e João Gilberto.

Após esse primeiro nível - a caracterização da desleitura no ritmo do canto -, ampliaremos nossa análise com a utilização dos pés-métricos, teorizados pela antiguidade grega. Essa ferramenta será imprescindível para um dos aspectos-chave de ambas as premissas trabalhadas nesse texto, pois, se em certos momentos, João Gilberto fortalece as escolhas interpretativas de Caymmi, em outros ele o desleituriza fortemente. $\mathrm{E}$ é na investigação dessas práticas específicas que acreditamos estar a chave para o entendimento do ato da desleitura, onde ao mesmo tempo em que se potencializa o fazer do influenciado que interpreta, por extensão se fortalece o influenciador/precursor no próprio ato de falsificá-lo ou interpretá-lo.

Os procedimentos desleiturizantes de João Gilberto acabam, de certa forma, fragilizando a busca pela identidade do estilo que, como veremos, não consegue ser entendido como algo completamente brasileiro, como queria João Gilberto, nem totalmente estrangeiro, como queriam seus detratores. Temos, portanto, o óbice, a impossibilidade de alcançar uma meta, já que a procura gilbertiana por uma interpretação específica da tradição da música popular brasileira e, consequentemente, a tarefa de alcançar uma identidade como artista, acabaria levando para um beco sem saída, um ser não sendo.

Acreditamos que isso ocorrerá devido a uma série de questões extremamente complexas e que, devido às condições que dispomos artigo, não serão mapeadas em sua totalidade. Iremos tratar de pelo menos uma dessas questões, a da desleitura. Acreditamos que ela acontece de maneira muito específica em João Gilberto, pois, ao mesmo tempo em que ele traz a famosa batida diferente, elemento que amplificará o rompimento com a tradição da música popular brasileira daquele período, ele não conseguirá se desconectar completamente de certos procedimentos de nossa tradição popular - o canto de Caymmi seria um deles -, impossibilitando assim, tanto a sua conexão plena com o nacional quanto a sua ligação inequívoca com os elementos musicais estrangeiros ${ }^{5}$. Nosso desejo é que esse artigo seja um convite para outras reflexões e abordagens sobre o assunto.

\section{I}

Como uma expressão artística é entendida como algo novo? A pergunta, no caso da Bossa Nova, está no centro das diversas disputas que envolveram esse estilo musical

$5 \quad$ Em 1989, numa entrevista ao jornal francês Liberátion onde o assunto principal era a orientação musical do show feito por ele em Montreaux, a entrevistadora chega a dizer que o show foi tão sambista que ela se pergunta se a bossa nova existia realmente. A resposta dada por Gilberto é diz: "O que significa essa história de Bossa Nova? Eu faço Samba". (GARCIA, 2012, p. 60). 
que surgiu no final da década de $1950^{6}$. O estilo seria marcado por uma série de polêmicas, sendo que uma das mais perenes é a acusação de que ela, a Bossa Nova, seria música feita a partir de materiais que não eram considerados genuinamente brasileiros.

Filha de aventuras secretas de apartamento com a música norte americana - que é inegavelmente sua mãe - a bossa nova, no que se refere a paternidade, vive até hoje (1966) o mesmo drama de tantas crianças de Copacabana, o bairro em que nasceu: não sabe quem é o pai". (...) Nós, da nossa parte, não vamos dar opinião. Para nós tudo o que é bossa nova, seja Johnny Alf ou Bud Shank, é americano. Pois eles todos, que são americanos, que se entendam. (TINHORÃO, 2012, p. 30).

Em um artigo de 1966, se questiona as conexões da Bossa Nova com a música tradicional brasileira:

Esse divórcio, iniciado com a fase do samba tipo bebop e abolerado de meados da década de 1940, atingiria o auge em 1958 quando um grupo de moços, entre 17 e 22 anos rompeu definitivamente com a tradição, modificando o samba no que the restava de original, ou seja, o próprio ritmo. (Idem, p. 37).

Essa acusação seria como uma espécie de ostinato, repetido ad nauseam por uma série de críticos nas mais variadas mídias ${ }^{7}$. Existiam opiniões deveras conflitantes com relação ao que realmente era a Bossa Nova, mas a questão das influências que formaram o estilo era uma tônica constante. Sobre a questão da influência, temos que

Qualquer performance envolve concessões, sendo uma adaptação inteligente da tradição para situações singulares estruturadas por uma confluência de diversos fatores. Só pode ser compreendida a partir de um largo espectro de performances de mesmo valor em contextos semelhantes e diferentes. (Honko apud FINNEGANN, 2008, p. 36).

Um artista se forma a partir de territórios que se sobrepõem, histórias que se entrelaçam, pois, o sujeito se faz através de contatos, entornos e vizinhanças e da mesma forma, o artista constrói sua identidade a partir de uma outra identidade. Temos que João Gilberto busca seu sentido artístico e uma de suas ações para alcançar tal intento é estabelecer uma forte conexão com a figura de Dorival Caymmi. Podemos apontar

\footnotetext{
6 Alguns autores - como, por exemplo, Castro (2008) e Tinhorão (2012) são enfáticos ao eleger o trabalho de João Gilberto no disco Chega de Saudade de 1959 como o acontecimento divisor de águas da Bossa Nova. Outros, como Gava (2002) indica a gravação de músicas como Chega de saudade e Bim-Bom, ambas lançadas como compacto no final de 1958, como o marco inicial do estilo. Entretanto, no que diz respeito às origens, as questões são mais complexas. Gava, por exemplo, discorda da opinião que apresenta a Bossa Nova com algo totalmente novo, logo, a questão da origem serve mais para apontar o início de certas modificações na maneira de se fazer samba do que o surgimento de algo estritamente original. Medaglia (2008), embora aceite que Chega de saudade é um marco indiscutível para a Bossa Nova, aponta que as verdadeiras origens do estilo devem ser situadas a partir dos trabalhos de Johnny Alf (1929-2010) e de Elizete Cardoso (1920-1990), com o disco Canção do amor demais de 1958 que conta com a participação da tríade Tom Jobim, Vinícius de Moraes e João Gilberto
} 
que o Caymmi será utilizado por duas questões básicas, a primeira é musical, já que muitos dos procedimentos harmônicos e interpretativos utilizados por ele iriam seduzir os futuros bossa novistas, que em meados da década de 1950 estavam descontentes com o tipo de procedimento que imperava na música popular brasileira ${ }^{8}$. Temos que João Gilberto dizia que seu trabalho era o de focar nas releituras, porque segundo ele existia muita coisa bonita a ser consertada. Em uma entrevista dada à revista Veja, de 1971, ele diz que a composição Rosa Morena foi utilizada como um verdadeiro campo de experiências na sua busca incessante pela melhor interpretação musical:

\begin{abstract}
Uma das músicas que me despertaram, que me mostraram que podia tentar uma coisa diferente foi "Rosa Morena", de Caymmi. Senti que aquele prolongamento de som que os cantores davam prejudicava o balanço natural da música. Encurtando o som das frases, a letra cabia dentro dos compassos e ficava flutuando. Eu podia mexer com a estrutura da música, sem precisar alterar nada. (CAYMMI, 2012, p. 376).
\end{abstract}

A segunda questão que determinou a escolha de Caymmi seria uma espécie de acordo simbólico, já que Caymmi possuía autoridade e era uma figura importante no cenário musical brasileiro, logo, sua benção ao estilo teria um peso considerável ${ }^{9}$. Naquele período, as músicas do último eram sucesso de crítica e público e ao se postar sob as asas desse Buda nagô (RISÉRIO, 1993), João Gilberto e a Bossa Nova se conectam ao samba. Ao se decidir por Caymmi, temos uma superação do elemento bairrista, ou seja, ao invés de optar por um tipo de samba específico, a estética bossa novista opta por ignorar a diferença que existe entres os sambas, seja ele o carioca ou o samba baiano. A Bossa Nova opta pelo Samba.

Caymmi (2008) utiliza o conceito de horizonte de expectativas, que seria o sistema de referências que se constrói em função de um conjunto de expectativas que, no momento do aparecimento de cada obra, "resultam do conhecimento prévio do gênero, da forma e da temática de obras já conhecidas, bem como da oposição entre linguagem poética e a linguagem prática". (JAUSS, 1994, p. 27). Isso nos faz entender o porquê de não haver uma radicalização estética: se os bossa novistas optassem por romper de forma inequívoca com a tradição, não haveria condições suficientes para que as obras fossem recepcionadas, nem absorvidas. Ela, a Bossa Nova, só foi aceita - e mesmo assim sob severas críticas que a fizeram ofegar durante um longo tempo - "porque trazia em si os elementos pertencentes ao horizonte de expectativas da época, caso contrário, seria rejeitada" (CAYMMI, 2008, p. 101).

\footnotetext{
$8 \quad$ Menescal (2003, p. 57), ao falar sobre isso, apresenta um viés bem comum aos futuros bossa novistas: "Você imagina a gente com 15 anos, com 16, 17 anos, começando a tocar violão, e a música que se tocava nas rádios nessa época era o samba canção, cuja letra não tinha nada a ver com a nossa geração que vivia em Copacabana, a primeira geração de praia. Não é a primeira geração que foi a praia, claro, mas foi a geração de praia que jogava futebol, jogava vôlei, namorava, tocava violão de noite na praia. Então você imagina a gente tocando clássicos assim como havia na época de Antônio Maria, por exemplo: "Ninguém me ama, ninguém me quer, ninguém me chama de meu amor". Ou aquela música do Antônio Maria, que dizia "Se eu morresse amanhã de manhã minha falta ninguém sentiria..." Nós éramos o contrário disso. Nós achávamos que todo mundo nos amava, que todo mundo queria a gente".

9 Em contrapartida, a Bossa Nova iria permitir o trajeto de Caymmi nas diversas temporalidades da música brasileira, fazendo com que ele fosse ouvido no contexto da Bossa Nova, incluindo-o de maneira específica no espaço simbólico do estilo, permitindo que novas gerações conheçam seu trabalho e dando a chance para que elas ouçam as obras feitas no então no tempo do agora (CAYMMI, 2008).
} 
Acreditamos que esse cenário poderia ser abordado a partir da utilização do conceito de Campo ${ }^{10}$. Bourdieu (1983, p. 89) define o conceito dizendo que o Campo seria um espaço social, um sistema de posições diferenciais que confere aos agentes que o ocupam papéis e status diversos. Ele é um território estruturado “(...) de posições (ou de postos) cujas propriedades dependem das posições nestes espaços, podendo ser analisadas independentemente das características de seus ocupantes."

Portanto, as posições ocupadas pelos indivíduos em cada espaço é que direcionam as ações que ocorrem no interior do campo. Nele, temos agentes e instituições que se engajam numa luta pela apropriação de um determinado capital, que ao ser acumulado, irá orientar as ações seguintes. Ainda sobre esse conceito, Araújo, Alves \& Cruz (2009, p. 35) observam que

\begin{abstract}
O conceito de campo é um dos conceitos centrais na obra de Pierre Bourdieu e é definido como um espaço estruturado de posições onde dominantes e dominados lutam pela manutenção e pela obtenção de determinados postos. Dotados de mecanismos próprios, os campos possuem propriedades que lhes são particulares, existindo os mais variados tipos, como o campo da moda, o da religião, o da política, o da literatura, o das artes e o da ciência. Todos eles se tornam microcosmos autônomos no interior do mundo social. A estrutura do campo é como um constante jogo, no qual, cientes das regras estabelecidas, os agentes participam, disputando posições e lucros específicos.
\end{abstract}

Ao empreendermos uma análise das relações entre agentes e instâncias dentro de um campo específico, partimos do pressuposto de que a arte nunca é descompromissada: ela sempre vai ter uma função monetária nesse comércio simbólico. Sob essa perspectiva, não há escolhas desinteressadas de temas ou mesmo de métodos, logo, "todas as opções que são feitas significam, antes de tudo, estratégias, investimentos orientados para a obtenção e acúmulo de capital e de lucro simbólicos" (ARAUJO, ALVES \& CRUZ, 2009, p. 32).

Dito isso, asseveramos que a moeda base para essas trocas simbólicas seriam justamente as obras que são produzidas nesses campos, verdadeiros artefatos culturais que ao serem operacionalizados nessa economia, resultam em posições culturais e espaços no interior do campo. Uma característica que seria imutável nos campos seria a luta que acontece entre o novo que entra e que tenta arrombar ferrolhos e subir níveis e o tradicional/ dominante que tenta defender o monopólio e excluir a concorrência ${ }^{11}$. Esse conflito sempre vai se desdobrar a partir da busca por uma legitimidade que servirá

\footnotetext{
10 O conceito de Campo marca uma ruptura na sociologia da cultura: ele foi construído pelo sociólogo Pierre Bourdieu (1930-2002) a partir de suas investigações sobre o sistema escolar francês e reflexões que envolvem o conceito de cultura, elite intelectual, formas de consumo e percepção artística. Suas contribuições conceituais entraram para o repertório teórico de estudos sociológicos, antropológicos, historiográficos e obviamente, musicológicos e com relação a teoria que iremos utilizar em nossa pesquisa, ela foi encaminhada na obra As Regras da Arte - gênero e estrutura do campo literário (1996).

11 Ao pensarmos na questão do poder simbólico e da sua influência na definição do campo, uma questão se apresenta: existe um tipo de organização ou um tipo de mecanismo que faça o campo funcionar sempre da mesma maneira? 0 próprio Bourdieu (1983) diz que essa visão é equivocada, pois ao mesmo tempo em que existem leis gerais no campo e que algumas delas possuem funcionamento invariante, cada vez que se estuda um novo campo descobrem-se propriedades específicas, próprias de cada campo e que mostram que os mecanismos genéricos agem de formas diferentes.
} 
não apenas para a obtenção de prestígio, mas também para a distribuição e aceitação da produção que é entabulada no interior de um campo. Esses agentes buscam conquistar posições simbólicas e para isso, implementam as tomadas de posição. Bourdieu vai organizar esse conjunto de práticas de conquista, que ocorrem no campo, a partir do conceito de estratégia.

\begin{abstract}
Os agentes sociais estão inseridos na estrutura e em posições que dependem do seu capital e desenvolvem estratégias que dependem, elas próprias, em grande parte, dessas posições, nos limites de suas disposições. Essas estratégias orientam-se seja para a conservação da estrutura seja para a sua transformação, e pode-se genericamente verificar que quanto mais as pessoas ocupam uma posição favorecida na estrutura, mais elas tendem a conservar ao mesmo tempo a estrutura e sua posição, nos limites, no entanto, de suas disposições (isto é, de sua trajetória social, de sua origem social) que são mais ou menos apropriadas à sua posição. (BOURDIEU, 2004, p. 29).
\end{abstract}

Pereira e Sarti (2010), ao tratar das relações que se estabelecem entre escritores e leitores ${ }^{12}$ definem que a estratégia corresponde ao cálculo de relação de forças empreendido por um sujeito detentor de algum tipo de poder que, por esta via, "(...) postula um lugar capaz de ser circunscrito como um próprio e, portanto, capaz de servir de base a uma gestão de suas relações cm uma exterioridade distinta". Ela busca organizar padrões e com isso, manter o poder simbólico de quem as implementa:

O capital específico ao campo é desigualmente distribuído e acumulado, o que motiva os agentes que buscam a sua posse na elaboração de estratégias de luta. Os agentes que monopolizam a autoridade específica ao campo tendem a organizar estratégias de conservação, em oposição aos novatos, que detentores de menos capital procuram subverter a dominação, articulando estratégias de subversão.

Com isso, temos o conceito de habitus, fundamental nas reflexões de Bourdieu. Cada campo tem uma lógica determinada e essa lógica é organizada de acordo com as possibilidades de movimentação dos agentes na estrutura do campo e essa movimentação decorre justamente do capital simbólico acumulado por esses agentes e é justamente o próprio campo que vai definir que tipo de capital merece ser acumulado ${ }^{13}$. Esse acúmulo de capital simbólico se orienta justamente no habitus, que é o conjunto de características específicas que vai levá-lo a acomodar-se ou a resistir e opor-se às forças do campo (BUSCACIO, 2013). Ele seria uma espécie de aptidão que orienta os agentes a agirem de maneira mais ou menos adaptada aos acontecimentos e situações.

Portanto, a estratégia, ao mesmo tempo em que ataca o que poderia transformar a estrutura do campo, serviria para defender e reproduzir as condições que geraram o

\footnotetext{
12 A questão da escritura e da leitura, que também foi abordada por Certeau em sua obra A invenção do cotidiano, nos interessam pela proximidade com a maneira que um intérprete lê a obra musical de outro artista. 0 entendimento e a interpretação de uma obra podem ser direcionados pelo compositor e pelo interprete que estreia a obra, porém, "os atos de criação e interpretação performatizados pelo músico desencadeiam operações que estilhaçam e multiplicam o significado que os enunciados estratégicos procuram impor como literal". (LANA, 2010, p. 7).

13 Bourdieu (2004, p. 26) entende que "cada campo é o lugar de constituição de uma forma específica de capital". No nosso caso, as manifestações culturais podem ser entendidas como bens, que podem ser acumulados e assim, seriam transformados em capital simbólico.
} 
habitus. Ela seria uma ação implementada por um reflexo oriundo do habitus, visando à reprodução mais inconsciente do que consciente de soluções típicas de uma tradição (TRIGO, 1998). É um conjunto de ações cuja eficácia independe do querer e do saber dos agentes. Com isso, o habitus instrumenta o sujeito a agir de forma adaptada, orientando-se no espaço social estrategicamente, sem que necessite de uma reflexão ou determinação consciente. É justamente por esse sentido mais passivo presente no conceito de estratégia que nos parece ser possível problematizá-lo ${ }^{14}$.

Faz-se necessário apresentar uma conexão entre o conceito de campo e o fazer artístico:

(...) um criador e sua obra são determinados pelo sistema das relações sociais, nas quais a criação se realiza, como um ato de comunicação e pela posição que o criador ocupa na estrutura do campo intelectual - este irredutível a um simples agregado de agentes ou instituições isoladas. O campo intelectual, ao modo do campo magnético, constitui um sistema de linhas de força: os agentes e instituições estão em uma relação de forças que se opõem e se agregam, em sua estrutura específica, em um lugar e momento dados no tempo. Cada um deles (agentes e instituições) está determinado por sua pertença a este campo, ou seja, à posição particular que ocupa, em especial a um tipo determinado de participação no campo cultural como sistema de relações entre os temas e os problemas e, por isso, a um tipo determinado de inconsciente cultural. $O$ seu poder no campo não pode definir-se independentemente de sua posição no campo. (LIMA, 2010, p. 14).

Dito isso, analisaremos como João Gilberto reorganiza certos aspectos interpretativos da obra de Caymmi visando não transformar a tradição sem abandoná-la completamente: o que ele faz é deformar a tradição através da desleitura. Essa ação deformadora seria, portanto, uma tomada de posição dentro de um campo simbólico.

\section{II}

Ao se ouvir determinada peça, trecho de canção ou um simples motivo musical, o que ouvimos soa como algo acabado, em bloco, um produto final cuja embalagem não nos permite escutar as emendas e pontos de fixação dos materiais utilizados na solução musical. Eles podem parecer translúcidos, mas esses pontos de costura de fato existem e são identificáveis. É a intertextualidade que caracteriza o fazer artístico, onde numa sutil polifonia, influências são aglutinadas originando uma obra específica; esta, por sua vez, será manipulada por outro artífice e somada a outras vozes. Com isso, temos que

(...) interpretar um texto não é dar a ele um significado (mais ou menos justifi-

\footnotetext{
14 Bourdieu vê a estratégia como um instrumento de ruptura com a ideia de ação sem sujeito que era defendida pelo estruturalismo, portanto, é necessário contextualizar sua obra, para evitar o que Trigo (1998) chama de leitura distorcida. Entretanto, alguns autores defendem que as estratégias não são tão passivas assim: "O "habitus", estas disposições adquiridas, este senso prático que orienta nossas condutas e faz com que tenhamos certas formas de ação, está relacionado ao fluido, ao vago e não tem origem numa regra explícita. São regularidades, e não regras, que construímos, jogando no nosso mundo cotidiano. 0 "habitus" serve de base para a previsão de nossas condutas porque, de acordo com ele, podemos agir de determinadas formas em determinadas circunstâncias. Esta tendência que temos para agir de certa forma não significa, contudo, que sempre façamos o que se espera ou a mesma coisa. Os agentes improvisam, elaboram novas estratégias, o que confere às estruturas simbólicas um papel maior e mais relevante". (ARAUJO, ALVES \& CRUZ, 2009, p. 38).
} 
cável, mais ou menos livre), mas ao contrário, apreciar a sua constituição plural. Num texto ideal, as redes de significação são muitas e interagem sem que nenhuma delas seja capaz de suplantar a outra. (Barthes apud SOUZA, 2009, p. 56).

A partir do momento em que um indivíduo - e em alguns casos podemos estender esse pensamento até mesmo para um grupo - entra em contato com determinado material acaba-se fazendo leituras específicas sobre esse algo e de certa forma, essas leituras passam a influenciar tanto a maneira de enxergar outros materiais, em um complexo jogo de relações de comparação.

(...) o sentido do texto não está em si mesmo, como afirma a noção familiar de significado, mas sim, na sua relação com outros textos, ele é apenas uma parte de um significado maior. Quanto à releitura ou reinterpretação, entende-se como uma busca por liberdade artística, manifestada através da utilização de trabalhos anteriores para fins próprios. Ela difere da leitura devido ao seu poder de revisão, de correção criativa. (BARBOSA, 2003, p. 127)

O tipo de intertextualidade que direcionará nossa abordagem será o de Bloom (2003) que fundamenta sua análise a partir de um espaço crítico fora dos limites do texto, a partir da comparação entre dois ou mais trabalhos literários. Esse autor observa que o leitor "partilha assim dos dilemas do revisionista, que deseja encontrar sua própria relação original com a verdade, seja em textos, seja na realidade", ou seja, ao pensarmos em termos de cultura e arte, cada indivíduo estabelece um tipo de entendimento e organiza uma abordagem sobre os materiais artísticos e isso desemboca no seu próprio fazer arte, pois como já dissemos anteriormente, quando lidamos com um objeto de leitura, o próprio objeto se modifica (BLOOM, 2003, p. 23).

Sobre isso, Pinto (2004, p. 50) diz que

A iniciativa do intérprete reordena a obra, na hora da fruição, e redefine seus significados. Pelo simples fato de que os repertórios coletivos sofrem alterações significativas quando são individualmente apropriados. Ou seja, a apropriação das referências gerais (...) assume dimensão específica e a compreensão possivel por cada indivíduo ganha contornos peculiares.

Bloom (2013) ao tratar de poesia, utiliza o conceito de desleitura, que seria a prática onde os poetas fortes constroem sua história distorcendo a leitura uns dos outros, a fim de abrir para si mesmos um espaço imaginativo:

Essas relações [entre obras] dependem de um ato crítico, uma desleitura ou desapropriação, que um poema exerce sobre o outro, e isto não difere em gênero dos necessários atos críticos que todo leitor forte realiza com todo texto que encontra. A relação de influência governa a leitura assim como governa a escrita, e a leitura, portanto é uma "desescrita" assim como toda escrita é uma desleitura. (BLOOM, 2003, p. 23).

Ela não é uma negação simplória da influência, uma simples recusa com relação aos antecessores: 
Nesse sentido, é dentro dela que o poeta constrói novos significados, partindo daqueles que foram trabalhados anteriormente por seus precursores, revisando -os e modificando-os, de modo a criar suas próprias ideias e imagens, atribuindo a elas significados próprios e abrindo, desse modo, um espaço para o seu lugar de fala no cânone literário. Para alcançar esse lugar de fala, portanto, o poeta deve "desler" aqueles que vieram antes deles. (OLIVEIRA, 2013, p. 5).

A luta entre artistas não é pessoal nem puramente material: ela se dá entre obras, e não entre personagens, entre poemas e não entre poetas:

Ameaçados pela perspectiva da morte imaginária, de sua inteira possessão por um precursor, sofrem de um tipo distintamente literário de crise. Um poeta forte busca não apenas vencer o rival, mas afirmar a integridade de seu próprio eu escritor (BLOOM, 2013, p. 21).

É justamente nesse ponto que a desleitura se conectará ao conceito de campo. Defenderemos a premissa de que João Gilberto desleituriza as obras de Caymmi, ressignificando elementos, redefinindo práticas e se apropriando de abordagens específicas, fazendo com que essa constituição plural se renda a um projeto de caráter único, específico, singular; o que antes era de um, agora é reformulado para servir aos conceitos de outro.

Ao estabelecermos nossa análise da desleitura em conexão com o ambiente cultural daquele período - final da década de 1950 - iremos propor a utilização do conceito de tática, que faz referência ao pensamento de Certeau (2013, p. 95):

\begin{abstract}
Chamo tática a ação calculada que é determinada pela ausência de um próprio. Então, nenhuma delimitação de fora lhe fornece a condição de autonomia. A tática não tem por lugar senão o outro. E por isso deve jogar com o terreno que the é imposto tal como o organiza a lei de uma força estranha. Não tem meios para manter em si mesma, à distância, numa posição recuada, de previsão e de convocação própria: a tática é movimento "dentro do campo de visão do inimigo" como diria Von Bullow, e no espaço por ele controlado. Ela não tem, portanto, a possibilidade de dar a si mesma um projeto global nem de totalizar o adversário num espaço distinto, visivel e objetivável. Ela opera golpe a golpe. Aproveita as "ocasiões" e delas depende sem base para estocar benefícios, aumentar a propriedade e prever saídas. O que ela ganha não se conserva. Este não lugar lhe permite sem dúvida mobilidade, mas numa docilidade aos azares do tempo, para captar no voo as possibilidades oferecidas num instante. Tem que utilizar, vigilante, as falhas que as conjunturas particulares vão abrindo na vigilância do poder proprietário. Aí vai caçar. Cria ali surpresas. Consegue estar onde ninguém espera. É astucia. Em suma, a tática é a arte do fraco.
\end{abstract}

Acreditamos que o conteúdo musical de um disco pode ser entendido como uma tática, pois nessa busca por posições dentro do campo, o produto artístico é um bem simbólico extremamente valioso, capaz de arregimentar defesas e potencializar outras práticas discursivas ${ }^{15}$. Ao tratar sobre questões envolvendo a notação musical e a maneira como o que está escrito se modifica na performance, Lana (2010, p. 7) aponta que 
Os atos de criação e interpretação performatizados pelo músico desencadeiam operações que estilhaçam e multiplicam o significado que os enunciados estratégicos procura impor como literal. Os movimentos táticos que eruditos e acadêmicos julgavam eliminados continuariam, portanto, como aponta Certeau, a determinar mudanças na cultura, organizando "a maneira de 'receber' as mensagens culturais, isto é, transformá-la pelo uso que delas se faz" (o grifo é nosso).

As táticas, portanto, seriam ações desviacionistas, que geram efeitos imprevisíveis e, diferente das estratégias que buscam "produzir, mapear e impor", as táticas originam diferentes "maneiras de fazer" (PEREIRA \& SARTI, 2010, p. 198). Com isso, entendemos que as táticas são as ferramentas dos que estão em posições de desvantagem e as estratégias serão operacionalizadas pelos elementos que estão em posições mais altas na hierarquia do campo ${ }^{16}$.

Porém, essa perspectiva se baseia, no pressuposto de que existe um poder localizável, que se impõe por meio de um modelo estratégico de ação e que dessa forma, assume eficácia social e no espectro oposto, os dominados não disporiam de um lugar próprio para inscrever suas práticas. Certeau observa que os táticos seriam "produtores desconhecidos, poetas de seus negócios, inventores de trilhas nas selvas da racionalidade funcionalista" traçando "trajetórias indeterminadas, aparentemente desprovidas de sentido porque não são coerentes com o espaço construído, escrito e pré-fabricado onde se movimentam" (CERTEAU, 2013, p. 91).

Entretanto, tal perspectiva nos parece de certa forma equivocada, pois "faz emergir uma concepção racionalista de poder, não totalmente adequada à análise das conjugações complexas que são estabelecidas entre liberdades e constrangimentos na sociedade contemporânea" (PEREIRA \& SARTI, 2010, p. 200). Se para Certeau, as táticas apenas deixam os seus efeitos como rastro e circulam sem ser vistas, deixando a vista apenas os seus produtos, cabe aqui uma indagação: a tradição só poderia ser modificada através do anonimato? Se levarmos em consideração esse tipo de argumento, toda ação modificadora seria uma estratégia. Porém, nem sempre as modificações são feitas por sujeitos que ocupam posições elevadas na estrutura do campo, o que caracterizaria a estratégia.

Além disso, a estratégia serviria para confirmar a estrutura do campo. O que seria então esse tipo de ação, oriunda de elementos menos poderosos e que ocupam lugares de certa forma invisíveis na estrutura do campo? Aliás, invisíveis para quem? Precisamos apontar que nem sempre essas práticas se apresentam em um cenário bem definido: por vezes ocorre um embaçamento dos limites entre quem é estratégico e quem é tático e entre quem é forte e fraco ${ }^{17}$.

Tanto quem implementa um modelo que na estrutura do campo será entendido como tradicional quanto quem faz uma desleitura dessa tradição possuem sim locais de

\footnotetext{
16 A partir desse momento, as reflexões de Pereira e Sarti (2010) serão utilizadas como a base em nossa problematização dos conceitos de estratégia e tática.

17 Ressaltamos que as categorias Estratégia/Forte e a Tática/Fraco se interpenetram, sendo extremamente difícil tratar de cada uma separadamente e é justamente por isso que iremos propor uma utilização específica do conceito definido por Certeau na sua obra $A$ invenção do Cotidiano (2013). Assim como o conceito de estratégia apresenta certas limitações, o conceito de tática deve ser utilizado com cautela, embora por razões que adiante apontaremos, ele seja o mais indicado para nossa análise.
} 
ação, pertencendo a um espaço temporal e histórico, defendendo agendas específicas a respeito de seus objetivos e implementando ações que, conforme o passar do tempo, acabariam tendo impacto no campo - ninguém transforma algo estando invisível e ignorando as modificações que serão impressas no seu fazer. Um leitor que lê um livro, assim como um músico que interpreta uma canção, percebem, em comparação com outros agentes que também leem e interpretam canções, que nem sempre a maneira como se entende e se canta é a mesma. Apesar do espaço de ação ser limitado devido ao poder e ao capital simbólico pertencente aos agentes em posições superiores no campo, as modificações são percebidas e pouco a pouco, elas podem se tornar referências.

Uma outra questão importante para nossos objetivos é que não se pode confundir o momento em que o procedimento tático é descoberto e finalmente imprime uma condição modificadora no campo de todo o processo subterrâneo em que uma série de procedimentos sincrônicos e diacrônicos se estabelece a partir do questionamento seguido de ações modificadoras. Deve-se ter em mente que a tática é o serpentear pelas brechas de um terreno que não se tem posse, mas que ainda assim, quem caminha de certa forma ocupa um lugar. Ultrapassando os limites que a fronteira da tradição demarcou, ele insiste, sobrevive e influencia o seu espaço com seus movimentos e ações, mesmo que sigilosos e, aos poucos, o resultado de suas ações tocará a superfície.

É através do conceito de temporalidade que podemos apreciar a forma com que ações táticas desencadeiam seu potencial transformador. A causalidade implica em manifestações da ação humana, tanto quanto se pode falar de causalidade difusa, neste contexto, é sempre mediada através do tempo. Ação tática, Certeau sublinha, opera junto a "trajetórias indeterminadas." Isto significa, numa primeira instância, que a tática funciona discursivamente, que transforma valores e torna-se visível e eficaz apenas através de maturação ao longo do tempo (MATOS, 2011, p. 5)

As interpretações de João Gilberto não são inéditas: elas seguem um rastro de uma série de outros intérpretes, como essas práticas se conectavam ao trabalho de brasileiros como Mário Reis (1907-1981) e Orlando Silva (1915-) e norte americanos como Frank Sinatra (1915-1998) e Chet Baker (1929-1988). Portanto, elas são desdobramentos de um longo processo de táticas que são feitas passo a passo, inclusive por Caymmi, cujo canto "privilegia mais a comunicação da letra do que a sonoridade operística da estética vocal perseguida pelas grandes vozes da época". (DOMINGUES, 2009, p. 63).

Tática seria a arte do fraco, uma vez que, quanto menor o poder, maiores são as possibilidades que o indivíduo terá para articular ações astutas. Porém, aqui temos mais uma questão a ser problematizada, pois acreditamos que a dicotomia entre ativos e passivos não se sustenta totalmente. Quem estabelece a tática deve ser considerado ativo - e de certa maneira, um forte. Esse sujeito que caça em terras alheias não seria um fraco, mas sim um agente extremamente competente. Aqui, novamente nos reportamos à conexão existente entre o músico e o leitor, pois no lugar de um leitor ingênuo e outro esperto, há um leitor plural. Sua face revela-se no ato da leitura pelas competências que possui e o encaminham para um tipo de específico de leitura: 
(...) Esses sujeitos procuram tirar proveito das escrituras anônimas que devem produzir por meio de uma postura de tipo tática: burlam suas regras, falseiam golpes de força, negociam alianças, captam reconhecimento ao encobrir escolhas subjetivas com a linguagem neutra da objetividade. Com isso, o escrito e o ato de escrever enredam-se mutuamente entre estratégias e táticas (PEREIRA \& SARTI, 2010, p. 202).

Ao se apropriar de uma obra, o leitor/músico manipula esse material, utilizando-o como um tipo de veículo para reflexão e autorreflexão, como base para refletir sobre si mesmo, os outros e o mundo a que pertencem. Mesmo que aceitemos a questão da dominação, a partir do momento que um anônimo estabelece uma relação com uma obra, ele passa a ocupar um espaço, ele deixa o vazio e passa a um lugar situado no tempo e no espaço em relação a obra que está sendo abordada. A obra atuaria como uma referência para a constituição da identidade e a distância se organiza, ou seja, a ideia de um não lugar se desfaz justamente pelo fato de que o leitor assume uma certa proximidade, colocando-se como "igual", solicitando informações, estabelecendo vínculos e diálogos com a obra. Portanto, a tática se estabelece pelas brechas, pela contestação a um padrão tradicional que é deslocado sutilmente, porém, o próprio ato de deslocamento imprime uma atitude especifica por parte do agente e com ela, a ocupação de um espaço.

Podemos afirmar que, as ações de João Gilberto irão permitir que ele conquiste certas credenciais que, progressivamente vão contribuir para adicionar um peso simbólico a sua obra, movimentando-o a níveis superiores dentro do campo caracterizando a feitura de uma ação estratégica, porém, outros requisitos inviabilizarão a implementação estrita dessa ação simbólica. A sua batida diferente e a especificidade de seu canto podem ser apontadas como bens simbólicos de alto quilate na economia do campo. $O$ próprio Tom Jobim observa que "foi João que deu aquele ritmo ao negócio. E não é só a questão da batida que João trouxe: João trouxe também a maneira de cantar, uma maneira de emitir, uma outra concepção toda desse negócio". (JOBIM, 2011, p. 59). Por outro lado, já apontamos como João Gilberto e a Bossa Nova serão recepcionados de maneira bem negativa por uma parcela da crítica e também do público.

Portanto, a Bossa Nova ainda estava organizando as suas bases e ainda assim de maneira tímida, tendo em vista a avalanche de críticas que lhe eram endereçadas desde o seu início ${ }^{18}$. Chegamos aqui a uma encruzilhada teórica, pois, devemos definir se a desleitura - cujos procedimentos iremos apresentar na próxima seção de nosso texto - seria uma tática ou uma estratégia. Acreditamos que o conceito de tática, apesar das limitações que possui seja mais eficiente para nossos objetivos, embora não se possa descartar que a ação tática possua elementos de estratégia. Trechos desse texto já fo- 
ram citados a pouco, mas transcrever a seção em sua totalidade será primordial para nossa abordagem:

(...) a leitura figura como uma atividade de tipo tática, tal como ensina M. de Certeau, mas que, sob determinadas condições, assume traços estratégicos relacionados à busca de um lugar próprio por parte do leitor. Nesses casos, a leitura apresenta-se como espaço de afirmação de uma temporalidade orientada pelos interesses e pela avaliação que o leitor faz dos textos que lhes chegam às mãos. Não se submete, em todos os casos, ao esquecimento e à indistinção das fontes, posto que permite ao leitor a capitalização, a comparação e a negociação (PEREIRA \& SARTI, 2010, p. 214).

Com isso, podemos apontar que a desleitura em alguns momentos pode ser tanto tática quanto estratégica. Chegamos a essa conclusão por três motivos básicos e para que eles sejam bem entendidos, deve-se ter em mente as relações que se estabelecem entre a escritura e a leitura ${ }^{19}$. Em primeiro lugar, o leitor tático de Certeau não é fraco e sim um leitor competente, a ponto de ter condições não apenas estabelecer um entendimento específico sobre o que está sendo lido, mas também de desleiturizar uma obra. Em segundo lugar, quem escreve a obra, ou seja, o predecessor que influencia o leitor, ao escrever estrategicamente, também instaura a sua ordem por meio da arte de dar golpes, pois

A escritura é, pois, um fazer tático derivado de lógicas pragmáticas da temporalidade, que uma conjuntura histórica transforma em poder estratégico, capaz de cumular o passado e (...) de conformar a alteridade do universo a seus modelos (Chartier \& Hébrand apud PEREIRA \& SARTI, 2010, p. 201-202).

\section{Portanto, em certos momentos estratégia e tática coexistem na mesma prática:}

É possível considerar, portanto, que em certos casos, as categorias tática e estratégia estabeleçam uma relação de interdependência regulada por um estado permanente de tensão que é reafirmado e atualizado no interior de cada experiência social e individual. (Idem, p. 214).

Com o lançamento do disco Chega de Saudade de João Gilberto, temos que a sua interpretação peculiar da obra de Caymmi irá contribuir para a organização de sua identidade artística ${ }^{20}$. Nisso temos uma possibilidade de entrevermos a estratégia, porém, no

\footnotetext{
19 A aproximação e interessante, pois, assim como na escuta musical, a leitura inventa vínculos, fundamenta tradições e a partir dela é possivel enxergar continuidades e cortes. Ela é uma tarefa construtiva onde reacomodações e ajustes permitem reescrever o texto, pois, "o leitor, na hora de traduzir para a escritura os livros lidos, reorienta o entendimento do que deveria ser absoluto: reescreve, recorre à citação - ou hipertexto - apoiada na memória individual, que é sempre controversa e corrói a possibilidade de uma memória total" (PINTO, 2004, p. 37).

200 pintor holandês Rembrandt (1606-1669) pode ser um referencial interessante nesse aspecto. Em sua época e com relação ao seu contexto, o mercado de arte do norte da Europa no século XVII, o estilo liso, do holandês grof, era o preferido não apenas dos artistas, mas também dos compradores, em oposição ao estilo rugoso, denominado fyn. Essa opção tem a ver não apenas com questões de cunho estético, mas também por certas reações culturais contra a posição cultural da arte numa região que ainda estava atrelada a um mundo artesanal dependente de guildas e ateliês, e não de uma sociedade letrada e privilegiada. Optando por utilizar o estilo rugoso, no contra fluxo daquela época, Rembrandt "atraía a atenção para seu ofício", impondo "a necessidade de distinguir-se, de isolar-se, de ser fiel a sim mesmo e, em suas obras da maturidade de constituir um "eu". Não um "eu" imposto pelo mundo exterior - como supõe a visão romântica do artista solitário e rejeitado -, mas um "eu" que ele mesmo inventou" (ALPERS, 2010, p. 90). Esse tipo mostra como certas obras, ao apresentarem aspectos idiossincráticos, podem potencializar a posição de um artista num determinado campo, exatamente como acreditamos que era o caso dos bossa novistas.
} 
caso específico de João Gilberto em sua relação com Caymmi, e a partir do contexto em que o disco Chega de Saudade foi lançado, acreditamos que ela seria mais tática do que estratégica. João Gilberto - e a Bossa Nova que ele representa - não possui força suficiente para imprimir uma ação simbólica efetiva, pois na cronologia do campo o estilo ainda é um jovem, logo, não teria condições de imprimir um peso considerável no campo.

Poderíamos então postular que a atitude desleiturizante de Gilberto seria de caráter tático, pois assim como uma série de interpretes que lhe eram anteriores, ele imprime golpes sucessivos - mas não completamente eficazes - na tradição que orienta as interpretações artísticas de nossa música popular. Aproveitando-se de uma tradição que lhe é familiar e de certa forma inescapável - devido as condições que se organiza o campo - ele estabelece uma distorção dessa mesma tradição, correspondendo ao tipo de postura tática que aos poucos vai abrindo brechas e possibilitando ações mais efetivas.

A questão do canto mais intimista, quase falado, distante da tradição do bel canto e dos arroubos melodramáticos presentes em boa parte dos samba canções daquela época, o surgimento da famosa batida diferente, a maneira de tratar a canção como um artífice que se aproveita dos espaços e dos ruídos inerentes à fala, a redução da massa sonora que inflava o samba daquela época, tudo isso pode ser apontado como contribuições fundamentais da Bossa Nova e que estão presentes nas interpretações de João Gilberto em Chega de Saudade. Porém, ainda se percebe a tradição do bel canto direcionando parte das interpretações vocais ${ }^{21}$.

Na última seção de nosso trabalho, defenderemos como a desleitura de João Gilberto opera nas brechas, problematizando a obra de sua figura influenciadora, apontando as imperfeições da obra e apresentando soluções para essas rachaduras. Essa atitude de correção corresponderá ao que Bloom entende como Clinamen, ou seja, uma leitura distorcida da obra de um artista. Em poesia, esse movimento corretivo "sugere que o poema do precursor segue até um determinado ponto, mas depois deve ter se desviado, precisamente na direção em que segue o novo poema" (BLOOM, 2002, p. 64). É justamente por esse tipo de procedimento gradual e corretivo, implementado por um agente sem muita força no campo que definiremos que a desleitura é tática, operando sutilmente, sem gerar alarde nem expectativa, mas que aos poucos se avoluma até virar uma tradição.

De certa forma, bebendo do conceito de polifonia bakhtiana e imprimindo uma postura de defesa da intertextualidade, Bloom (2003) aponta que não existem textos isolados e sim relações entre textos, ou seja, todo texto é feito de muitas de redes de

\footnotetext{
21 Salientamos que a Bossa Nova seria um fenômeno basicamente inscrito na região sudeste. Em outras regiões, dificilmente poderíamos dizer que seu alcance foi tão estrondoso e com isso, os procedimentos que ela popularizou eram reproduzidos em menor escala do que no Rio de Janeiro e em São Paulo. Sobre a questão das interpretações vocais, a utilização do belcanto não era apenas devido a aspectos estético musicais. Antes do advento da tecnologia eletromagnética de gravação, as gravações era feitas de forma estritamente mecânica. Nessas, o som era captado por um cone de metal e transmitido mecanicamente para a agulha gravadora, que criava um sulco na cera, registrando o espectro de som. Apenas em 1927 o cone seria substituído pelo microfone elétrico, mais sensível (BESSA, 2010). Portanto, para que a gravação pudesse ser feita de forma mais eficiente, era necessário que o canto fosse potente. Entretanto, mesmo depois das modificações técnicas, a música popular brasileira ficaria marcada com esse tipo de interpretação vocal.
} 
significação que interagem entre si. Destarte, o artista sempre deseja encontrar sua própria relação original com a verdade, com a sua verdade artística e para isso precisa depurar a certos níveis as constituições plurais que formam o seu texto artístico. Dito isto, buscaremos possibilitar o entendimento de que as gravações de João Gilberto podem muito bem ser um exemplo de táticas que, como já apontamos, teriam também características estratégicas, agindo a serviço de um projeto de legitimação dentro de um campo simbólico.

Certeau (2013), ao discutir a cristianização a que eram submetidos os povos indígenas da América do Sul, observa que se agiam em dois níveis distintos: em um, externo, os indígenas se submetiam aos colonizadores, parecendo se conformar com as expectativas dos seus dominadores. Num outro nível, subterrâneo e extremamente sutil, eles metaforizavam a ordem dominante, fazendo funcionar as suas leis e representações num outro registro, no quadro da própria tradição. Portanto, a presença e a circulação de uma representação ou de uma prática não indicam, de modo algum, o que ela é para seus usuários. É ainda necessário analisar a sua manipulação pelos praticantes que não a fabricaram.

Aqui estabelecemos um paralelo entre a possibilidade de utilizar a música como uma tática e a partir desse entendimento, a desleitura seria a ferramenta desse procedimento de correção. Para fundamentar nossos posicionamentos e confirmar nossas opções teóricas, utilizaremos a análise musical para indicar o último elemento que completará nossa premissa fundamental, a de que a desleitura opera como tática e que aponta para um determinado projeto de identidade artística.

\section{III}

A música Rosa Morena ${ }^{22}$ foi escolhida por que seu autor, Dorival Caymmi, é uma das influências plenamente reconhecidas de João Gilberto e é apontado como uma das peças fundamentais no processo de legitimação do estilo perante o público:

No jornal Diário Carioca (19.11.1958), foi publicada uma foto de Caymmi e João Gilberto, acompanhada da legenda que promovia o novo disco do cantor estreante: Caymmi e João Gilberto. O primeiro famoso; o segundo, cantor e violonista dos mais promissores, com sua arte, brevemente conquistará a consagração popular. Artista de grandes recursos, agora contratado da Odeon, estreou de maneira magnífica com as gravações curiosas de "Bim Bom" e "Chega de Saudade. (CAYMMI, 2008, p. 132).

Joly (2012, p. 49) aponta que "uma análise não deve ser feita por si mesma, mas a serviço de um projeto" e que "definir o objetivo de uma análise é indispensável para

\footnotetext{
22 De início precisamos explicar porque escolhemos a gravação de Caymmi, que foi feita em 1955 ao invés da primeira gravação de Rosa Morena, que ocorre em 1942 com o grupo Anjos do Inferno. Dialogaremos com a versão de Caymmi porque a relação entre a sua maneira de pensar a harmonia e a sua interpretação peculiar da canção tem mais conexões com o tipo de pensamento que João Gilberto apresentava e essa assertiva será baseada pelos resultados de nossas análises. Podemos ser acusados de priorizar uma gravação que nos convém, em detrimento da outra, mas esse tipo de acusação não se sustenta devido aos testemunhos do próprio João Gilberto que diz reiteradamente que foi o trabalho de Caymmi, e não o dos Anjos do Inferno, que serve de modelo referencial para suas experiências sonoras.
} 
instalar suas próprias ferramentas, lembrando-se que elas determinam grande parte do objeto da análise e suas conclusões". Sob essa perspectiva, acreditamos que a análise de certos elementos dessa obra nos darão indícios ${ }^{23}$, pistas de como e por quê João Gilberto numa desleitura específica, se aproximava do modelo de interpretação de Dorival Caymmi ao mesmo tempo se afastava dele, ou seja, ao mesmo tempo em que se concorda com a tradição, se faz um questionamento e uma modificação.

O próprio Caymmi, numa fala de 1995, diz que

E é o que João Gilberto é: ardiloso. Ele levou ao máximo esse jeito de ser ardiloso. E olhe, com um atrevimento (...). Você sabe que a gente reparando bem, sem querer ser sábio nem sabichão - sobretudo sabichão, que eu não sou - mas é que são aquelas esperas: "Rosa [cantarola o samba] deixa a zona vazia para você botar o molho. E João Gilberto é um ourives nessa coisa de espaço vazio, ele deixa a bola na sua mão sabendo que ele vai tirar. É um ardiloso! (...) Então ele vem assim: "Rosa" [canta] e o vazio que fica aí, para você pensar em acabar o mundo. (GARCIA, 2012, p. 84).

Caymmi chama Gilberto de ardiloso, numa brincadeira que deixa transparecer não apenas o grau da amizade e informalidade que existe entre eles, mas assinala como ele entende os artifícios interpretativos do bossa novista. $O$ termo ardiloso assume aqui o significado do artista que ao se deparar com um determinado artefato artístico, consegue entendê-lo e remodelá-lo a seu bel prazer, encontrando soluções para desequilíbrios e optando por diferentes tratamentos que outros artífices não conseguem dar. A respeito disso Ostrower $(2009$, p. 51) nos fala que "todo processo de elaboração e desenvolvimento exige um processo dinâmico de transformação, em que a matéria, que orienta a ação criativa é transformada pela ação".

Utilizaremos a gravação de Caymmi como referência e baseando na estrutura com que ela é executada, iremos seccionar a música Rosa Morena em três seções básicas. Essa divisão irá possibilitar o empreendimento da última etapa de nossa análise, onde aventaremos a possibilidade de João Gilberto estar fazendo uma desleitura da interpretação rítmico-vocal de Dorival Caymmi:

a) A primeira que chamaremos de A vai do início da frase Rosa Morena / onde vais morena Rosa até o verso e esse andar de moça prosa / morena / morena Rosa, num total de dezoito compassos;

b) A segunda, B, se inicia com a melodia em anacruse, e a frase Rosa morena o samba está esperando, encerrando-se na frase Anda Rosa / vem me ver, totalizando dezesseis compassos.

c) A terceira e última seção, com dezoito compassos, começa com o verso

\footnotetext{
23 Aproximamo-nos aqui do conceito de paradigma indiciário de Ginzburg (1983), que se baseia no entendimento de certos indícios como zonas privilegiadas de uma opaca realidade e que dessa forma permitem decifrá-la. A partir da análise do atípico, do que não está na média, do que está situado em extremos e até mesmo do que já foi observado, mas que agora será retrabalhado, ou seja, ao analisarmos esses indícios seria possivel apontar uma possibilidade de deciframento em certos aspectos, novas faces de uma questão, como se fossem chaves para o acesso a um viés diferente.
} 
Deixa de lado essa pose e termina com a música na frase Que o pessoal tá cansado de esperar. As frases finais são repetidas pelos dois interpretes. Chamaremos essa mini seção de C1 e essas repetições de C1, C2 e C3.

Salientamos que a estrutura da gravação VDC - Versão Dorival Caymmi - não segue a mesma forma que ocorre na de João Gilberto.

a) Caymmi canta o que seria o $A$ apenas uma única vez, enquanto Gilberto canta duas, chamaremos a primeira de $A(1)$ e a segunda de $A(2)$.

b) Após uma pequena seção instrumental, ausente na gravação de João Gilberto - que de agora em diante será a VJG, Versão João Gilberto -, Caymmi canta a seção B (1);

C) Após o B, antes da seção instrumental Caymmi canta C e depois C1. Após a seção instrumental, canta-se a seção $B(1)$, seguida de $C$ e a mini seção $C 2$. João Gilberto opta por repetir a mini seção três vezes, formando o que chamaremos de C1, C2 e C3.

Agora, o primeiro exemplo a ser discutido no nosso empreendimento de comparação entre a interpretação dos dois artistas.

Na seção B, enquanto Caymmi usa o silêncio, enquanto Gilberto estende as notas, fugindo do espaço vazio. Esse é de certa forma um procedimento de certa forma alienígena, estranho, já que João Gilberto é conhecido pela sua utilização dos espaços vazios e do silêncio como ferramenta de interpretação.

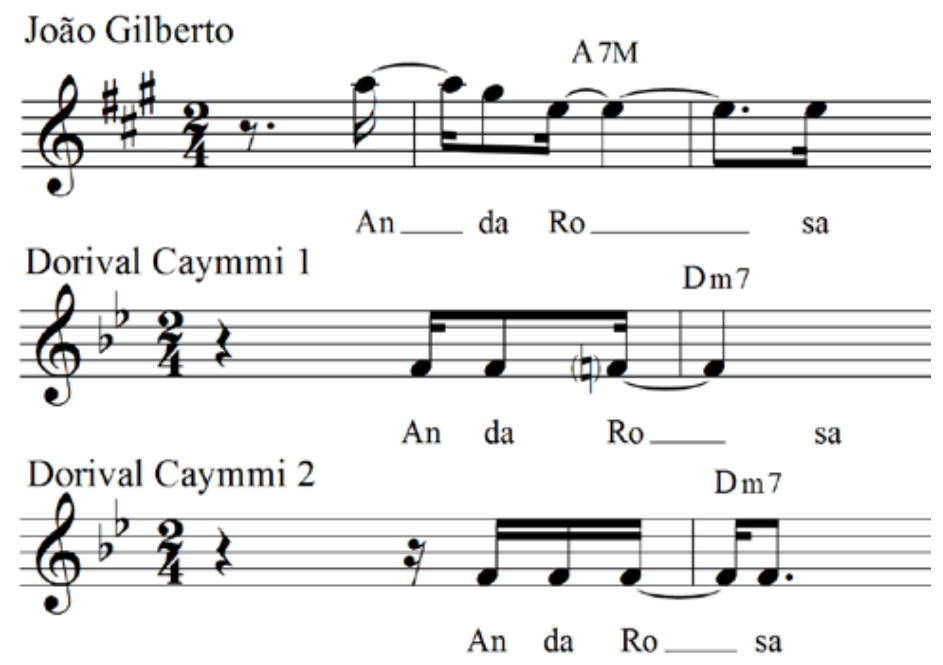

Exemplo 1. Rosa Morena. Comparação entre os silêncios de Dorival Caymmi e João Gilberto. Seção B.

Ao focarmos no aspecto rítmico da interpretação vocal da música Rosa Morena, percebemos que em determinados pontos as interpretações ora se aproximavam literalmente, ora se distanciavam bruscamente. Isso é um fato óbvio se pensarmos que cada intérprete se estabelece com um tipo de abordagem específica da obra, de acordo com seus referenciais estéticos que se explicitam na forma com que ele trata o material musical. Desnecessário dizer que ninguém interpreta uma obra da exata maneira como o autor ou o intérprete antes dele fez.

Porém, ao nos esquivarmos de uma análise puramente preto no branco, onde ape- 
nas se aponta o que está igual e o que está diferente da interpretação que se tem por referência, percebemos que a forma como Gilberto trata o material de Caymmi apresenta atitudes tanto de aceitação quanto de rejeição em níveis distintos. Em alguns momentos o distanciamento é total, em outros, parcial, como numa aproximação da obra de referência, mas até mesmo essas aproximações são feitas em níveis distintos, num constante descarte e encaixe de elementos musicais.

Podemos apontar um exemplo do que chamaremos de repetição e de distanciamento, desta vez por inversão, ou seja, na maior parte do trecho, João Gilberto canta a mesma divisão rítmica que Caymmi. Entretanto, no trecho indicado ele se distancia do original ao inverter a divisão rítmica que lhe serve de referência. A inversão está no terceiro compasso:

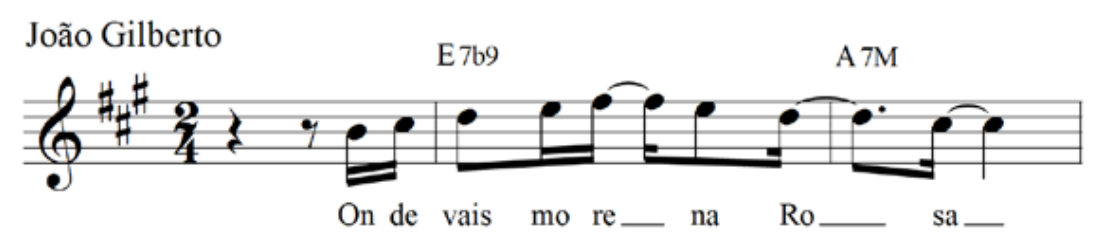

Dorival Caymmi B, $7 \mathrm{M}$

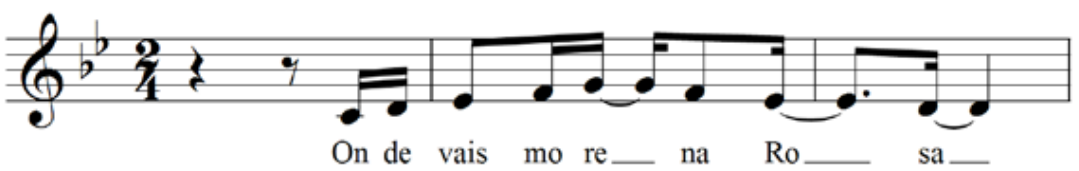

Exemplo 2. Rosa Morena. Exemplo de repetição e distanciamento por inversão entre as interpretações de Dorival Caymmi e João Gilberto. Seção A.v

Aqui, um exemplo de repetição, ou seja, João Gilberto, na maior parte do trecho, usa a mesma divisão rítmica oriunda na interpretação de Caymmi:

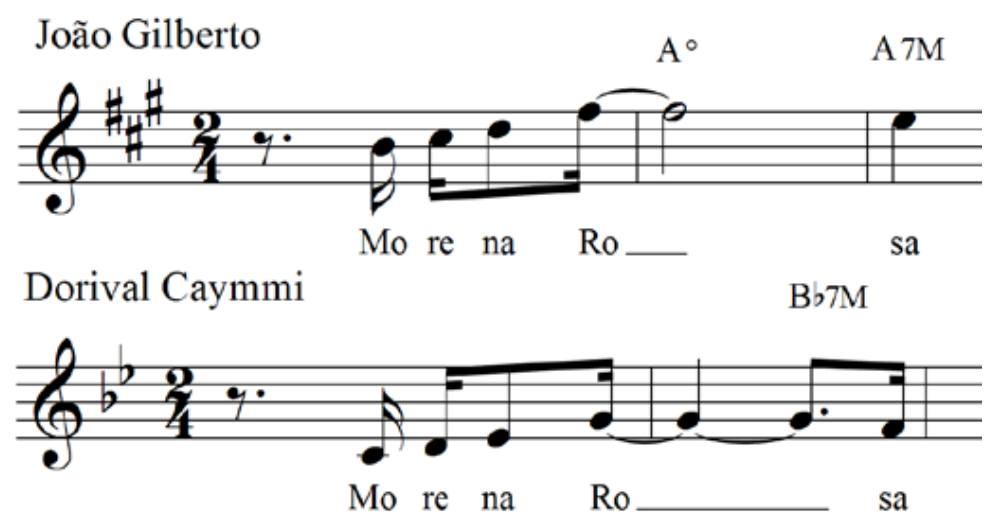

Exemplo 3. Rosa Morena. Exemplo de repetição na interpretação de João Gilberto com relação à interpretação de Dorival Caymmi. Final da seção $A$.

A modificação do discurso musical é a tônica em todos os exemplos, nunca o lite- 
ral permanece por muito tempo e mesmo as modificações são pontuais, nunca descaracterizam totalmente as relações com a interpretação base. É como se João Gilberto aproveitasse o que lhe interessa na interpretação e descartasse o que para ele fosse desnecessário. Tatit (2004) ao falar da aparente ruptura da Bossa Nova com o Samba chama isso de decantação, um processo de triagem de ordem estética em que se decanta a canção brasileira de qualquer característica muito acentuada. Porém, apenas apontar diferenças e similitudes em performances específicas desses dois artistas não nos parece um caminho interessante, mas somente até certo ponto, já que outros elementos musicais se mostraram interessantes de serem analisados e que destarte, poderiam melhorar ainda mais nossa compreensão do que seria a desleitura.

Ainda podemos identificar certas questões que se apresentam embaçadas, no que diz respeito às aproximações e distanciamentos nas relações entre as interpretações dos dois intérpretes, por isso decidimos aprofundar um pouco mais a análise. Além da análise focada nos aspectos rítmicos do fraseado, iremos daqui em diante atentar para as acentuações - as relações entre as paridades longa/forte - curta/fraca ${ }^{24}$ - que os artistas imprimem nas suas interpretações vocais. Com isso, passaremos a empreender uma análise das acentuações presentes nesses trechos, utilizando como elementos de referência os chamados pés-métricos, teorizados pela antiguidade grega para referir-se à prosódia do verso.

Apesar das acentuações se conectarem a questões do fraseado ligadas ao volume, intensidade, ênfase e timbre, ainda assim elas estão estritamente conectadas ao elemento ritmo, pois estão inseridas em pontos temporais no interior das frases. Para Schoenberg (2012), o ritmo é um elemento particularmente importante para moldar a frase, pois ele contribui para seu interesse e variedade e determina seu caráter e sua unidade. Alguns dos elementos constitutivos do fraseado podem ser utilizados na busca por variação, porém, toda variação na realidade envolve necessariamente um tipo de repetição que pode ser literal, modificada ou desenvolvida. No caso de Gilberto, percebe-se que todas as três formas de repetição se apresentam, porém, a questão é: até que ponto uma repetição que parece ser literal é realmente literal? E se estendermos essa pergunta no âmbito da comparação entre Gilberto e Caymmi: até que ponto o que parece ser literalmente idêntico não é na verdade modificado e o que parece ser inteiramente modificado não é literal? A partir daí que optaremos pela análise e pela comparação das acentuações presentes no fraseado de ambos os intérpretes.

Cooper e Meyer (1963, p. 6) apontam que a definição de ritmo seria "o modo no qual uma ou mais notas não acentuadas são agrupadas em relação a uma nota acentuada". A partir da relação entre acento e não-acento, entre forte e fraco, surge a possibilidade de fundamentar nossa abordagem a partir da comparação entre as acentuações presentes nos fraseados, utilizando os pés-métricos, que em sua origem eram operacionalizados

\footnotetext{
24 "Dia e noite, forte e fraco, Dike e Hybris, vida e morte, longa e curta formam pares simétricos cuja polaridade é essencial para a percepção de tempo e para a noção de identidade. Não à toa uma paridade simétrica longa/forte - curta/fraca e suas relações pode ser observada em Cooper \& Meyer no que diz respeito à música, em Antônio Candido no que diz respeito ao verso e em Platão no que diz respeito à estrutura do movimento. Essa alternância entre pares aponta para especulações sobre a gênese do plano temporal no que diz respeito à consciência, à episteme e à percepção, e no que diz respeito Às artes, sobre sua origem comum: um momento perdido no qual música, lírica e gesto ainda não haviam se separado e faziam parte de um mesmo evento" (MENEZES, 2012, p. 22).
} 
para referir-se à prosódia do verso nas formas poéticas da antiguidade grega.

Existem algumas questões que devem ser apontadas ao utilizarmos essa abordagem e elas surgem principalmente devido às características específicas da língua grega em relação à língua portuguesa e por extensão, à música aqui produzida ${ }^{25}$. Entretanto, acreditamos que utilizar os pés-métricos em nossa pesquisa de maneira nenhuma arruinará nossa abordagem das relações entre o fraseado de João Gilberto e Dorival Caymmi. Surgem limites, pois existem questões específicas que estão presentes no contexto da poética grega, mas acreditamos que, ao aplicarmos os pés-métricos estaremos utilizando um método de análise que possui um potencial explicativo interessante para nossos objetivos e que não pode ser descartado devido à distância temporal entre a rítmica da Bossa Nova e o tipo de pensamento musical oriundo da antiguidade grega. Essa é uma operação em que se busca desfossilizar um método analítico, não se deixando escravizar pelo contexto e pela definição estrita de um conceito: "essa é por diversas vezes uma operação importante para escapar da estagnação discursiva" (BARROS, 2011, p. 245).

Reproduzo aqui a tabela dos pés-métricos ${ }^{26} \operatorname{com}$ os seus sinais prosódicos, extraídos e selecionados da extensa lista apresentada por Messiaen (1992)

\footnotetext{
25 Um exemplo é o apontado por Menezes (2012) que assevera o fato de que o verso grego, que constitui uma unidade de música e língua abarcada pelo conceito de mousiké, resulta não da sucessão de diferenças qualitativas de acentos - sílabas tônicas e átonas, como por exemplo, na língua alemã - mas de uma sucessão qualitativa de elementos breves e longos, podendo os primeiros ser acompanhados por uma elevação do pé (arsis) e os segundos por um abaixamento do pé (thesis). Além disso, os sinais obscurecem as relações entre os aspectos métricos e a intensidade da batida - aqui entendida pelo que chamaremos de pulso. Nosso metro de referência será aquele que corresponde ao compasso binário. Os elementos que formam essa estrutura podem ser chamados de pulso, termo utilizado em pesquisas de língua inglesa, onde cada pulso também pode ser chamado de beat, quando se deseja localizar o pulso dentro do compasso como forte ou mais fraco. Conforme apontado por Menezes (2012), essas definições ainda não estão bem definidas entre os autores. Optamos utilizar em nossa pesquisa o termo pulso, onde ele formaria "diversos níveis métricos da música, sendo que um desses níveis pode ser eleito o pulso de referência, que integra o compasso e é análogo às batidas do metrônomo". (MENEZES, 2012, p. 29).

26 A tabela que apresentamos é a que foi utilizada por Messiaen (1992), portanto, os termos estão no original, em francês. Em nosso texto, optamos por traduzir alguns dos termos, seguindo os procedimentos utilizado em outros trabalhos que usam a mesma ferramenta de abordagem rítmica: Dactyle: Dáctilo; Trocée: Trocaico; Anapeste: Anapéstico; Pariambe: Pariâmbico; Spondé: Spondaico; Anphibraque: Anfibráquico.
} 


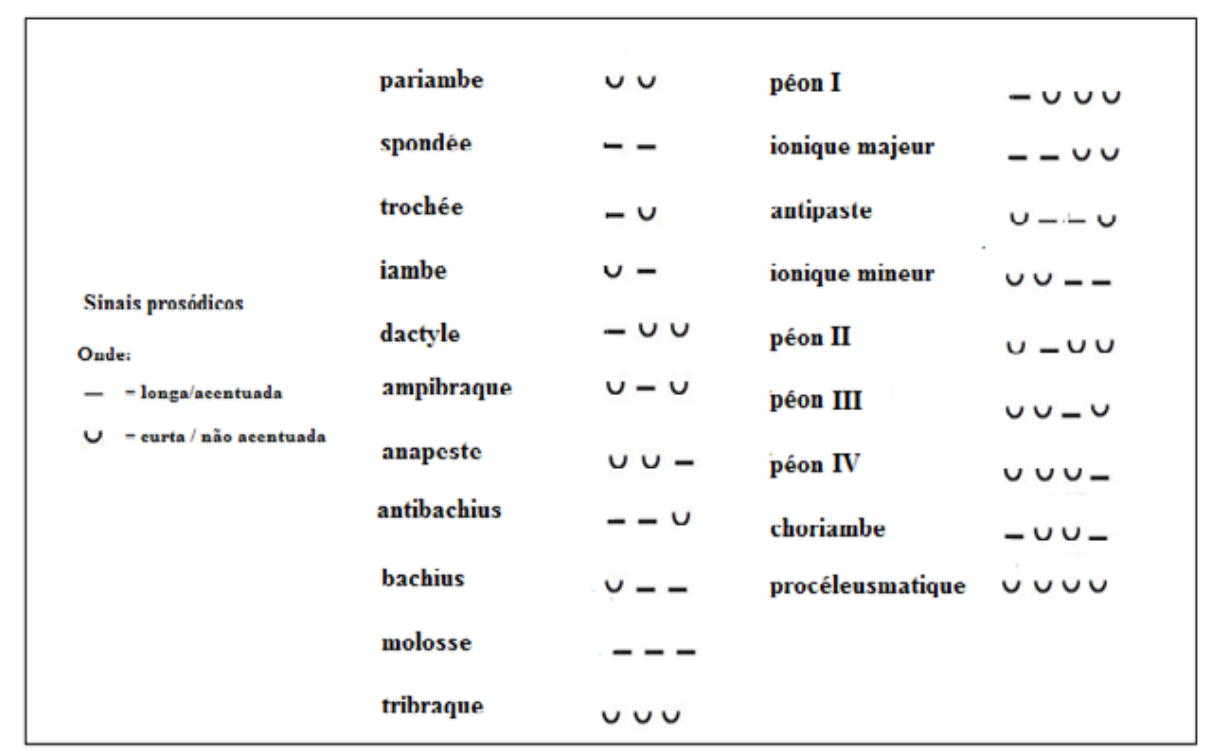

Quadro 1. Pés-métricos.

Queremos deixar claro que esses sinais irão funcionar não como ferramentas para uma análise total, baseada estritamente nos conceitos da prosódia grega, mas operacionalizaremos essas referências como ferramentas analíticas, visando a exposição das acentuações sem remetê-las de maneira inequívoca ao tipo de pensamento que guiava a poética grega ${ }^{27}$ :

Há nesse pressuposto um nível de diferenciação entre duração e acento, consequência do convívio de dois postulados diferentes: o de que música e fala tem a mesma origem real e o de que isso não pode passar de uma metáfora (...). Operar com essa tensão implicará uma zona de indiferenciação entre ritmos da fala e da música. Essa zona corresponde à prosódia. Se a métrica tradicional considerava as longas acentuadas como tendo o dobro da duração das curtas não-acentuadas, em termos modernos teremos que lidar com notas de mesma duração ou muito diferentes, que podem ser ora acentuadas, ora não, realizadas em uma língua que não é o grego arcaico, dentro do cancioneiro popular de um país em tudo diferente da Grécia Antiga. Ao utilizar esses sinais, o musicólogo não pode realizar mais que uma metáfora, embora eles apontem para uma relação real entre música e fala, ainda observável em nosso cotidiano. (MENEZES, 2012, p. 23)

Temos, portanto, a consciência de que a utilização desses sinais deve ser feita com cuidado, principalmente devido à diferença da sintaxe entre poesia e música e a distância que se apresenta entre os contextos linguísticos, musicais e culturais do mundo da antiguidade grega e o cenário artístico brasileiro da década de 1950. A análise das acentuações trará aspectos do discurso musical de ambos que, numa observação superficial, se apresentavam soterrados até mesmo despercebidos e que ao serem desnudados pela análise funcionarão como indícios que, ao serem iluminados pelo referencial 
teórico que indicamos anteriormente, contribuirão para uma perspectiva mais profunda da questão da desleitura que Gilberto faz de Caymmi.

Destarte, precisamos deixar claro qual é nosso entendimento com relação ao que seriam acentos e salientamos que não é um assunto simples: as reflexões envolvendo esse assunto deram origem a diversas definições e devido a esse número expressivo de perspectivas, surge a necessidade de basearmos nossa abordagem em um ponto conceitual restrito. Acreditamos que a definição dada por Cohen (2012, p. 83) pode dar conta dessa questão:

Acento é um fenômeno relacional que delimita uma configuração, e é causado por muitos fatores cuja combinação pode tornar certos pontos mais ou menos salientes (enfáticos) com relação aos outros que o circundam.

Deve-se levar em conta que essa gama de fatores seria responsável pela acentuação de determinadas notas, consideradas como pontos de ênfase em relação aos pontos que a circundam, como aponta Lester (1986). Dito isso e usando as categorias classificatórias dos pés-métricos, ao compararmos as interpretações de Caymmi e Gilberto na seção final de Rosa Morena, o que temos são as seguintes marcações:

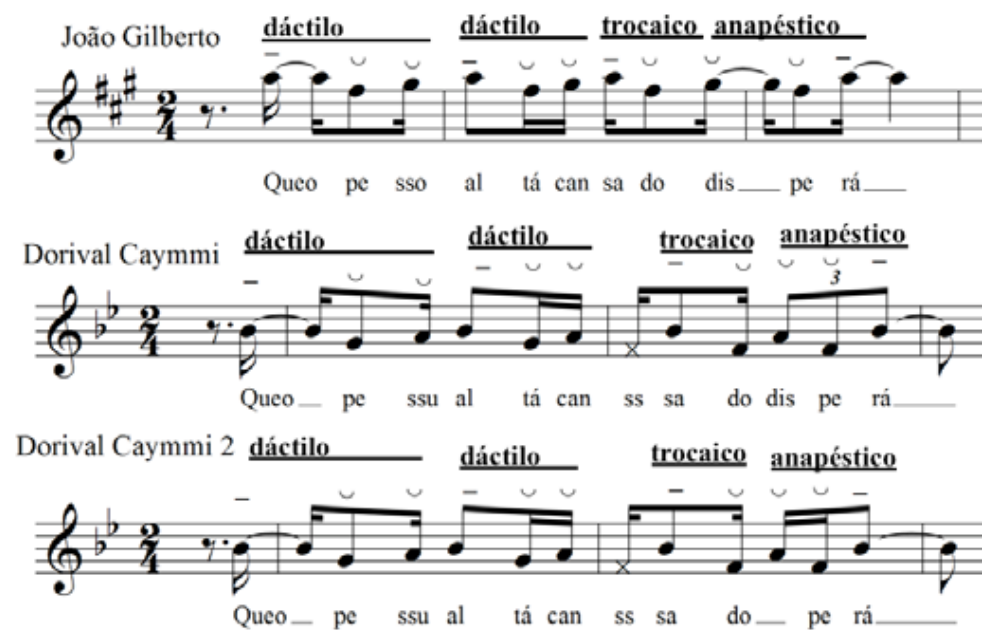

Exemplo 5. Rosa Morena. Comparação entre os pés-métricos utilizados por João Gilberto e Dorival Caymmi no final da seção C.

As interpretações rítmicas de ambos divergem entre si em pontos muito sutis e com relação aos pés-métricos, os agrupamentos se repetem ${ }^{28}$. Podemos dizer que, apesar dessas diferenças na divisão rítmica do fraseado, apenas aparentemente as duas interpretações diferem, pois num outro nível - e aqui estamos nos referindo à acentuação que ambos imprimem ao seu canto - a interpretação de Gilberto segue o mesmo tipo de estrutura da acentuação feita por Caymmi. Para fortalecer ainda mais nossa posição 
com relação a essa questão, iremos analisar um trecho em que a divisão rítmica é quase idêntica - apenas no final Gilberto estabelece uma inversão -, porém, ao analisarmos a partir do esquema dos pés-métricos, surge uma conexão entre ambos que não seria tão clara se baseássemos nosso olhar apenas para a divisão rítmica do fraseado:

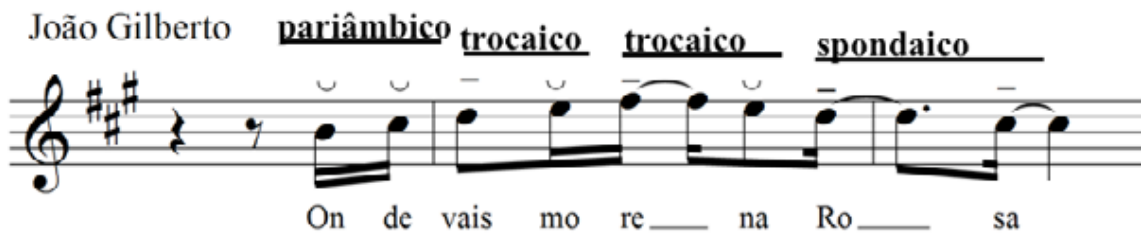

Dorival Caymmi pariâmbico trocaico trocaico spondaico

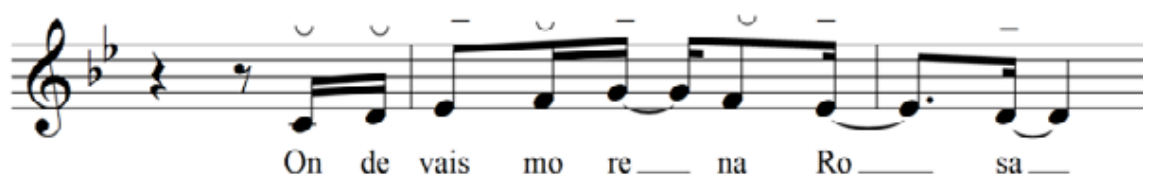

Exemplo 6. Rosa Morena. Comparação entre os pés-métricos utilizados por João Gilberto e Dorival Caymmi na seção A.

Temos nesse ponto uma pergunta importante: será que a acentuação é inerente ao tipo de fraseado que se estabelece nesse trecho da música, impossibilitando João Gilberto a modificá-la? A resposta é: não. Se compararmos o A2 de João Gilberto com o A1 de Caymmi o que percebemos é um deslocamento da melodia original, gerando com isso uma nova acentuação.
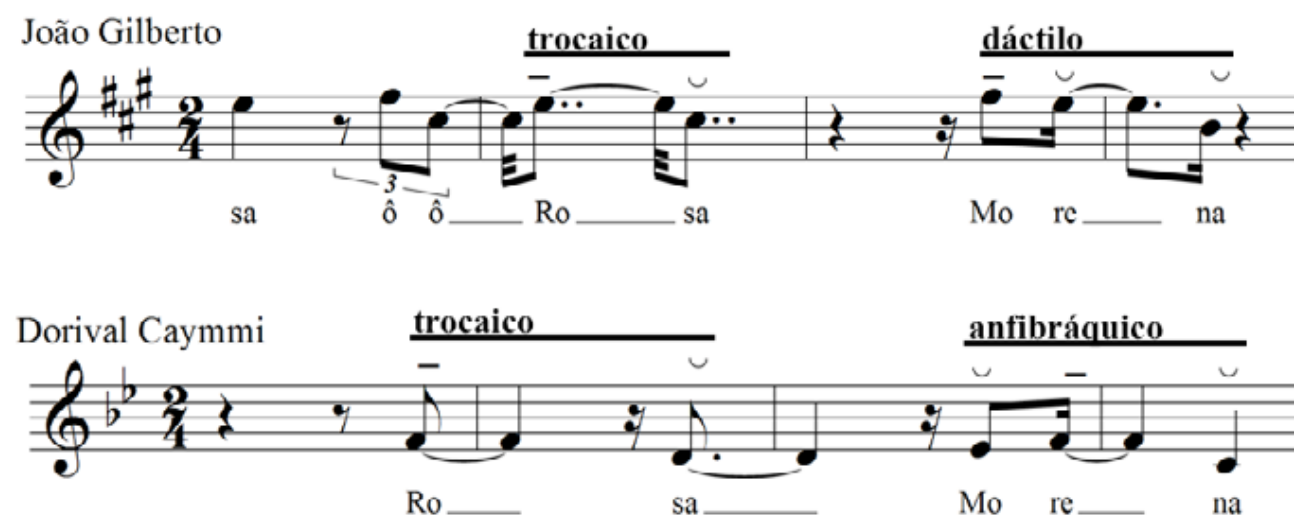

Exemplo 7. Rosa Morena. Comparação entre os pés-métricos utilizados por João Gilberto na seção A2 e Dorival Caymmi na seção

Com isso, temos que, ao se mudar uma divisão rítmica de um fraseado, nem sempre a acentuação original é modificada e da mesma maneira, ao se optar por manter a mesma estrutura rítmica não significa que a acentuação original do fraseado permanecerá. A manipulação e transformação dos materiais musicais pode ser utilizada ao mesmo tempo para fortalecer quanto para fragilizar uma performance tida como uma 
referência: é nesse aspecto que temos a desleitura em ação.

O início do trecho Rosa morena o samba está esperando, que está na seção $B$, é idêntico nas duas interpretações, pois ambos optam por utilizar um fraseado baseado em tercinas, que nesse caso seriam responsáveis por trazer mais fluidez à interpretação devido a uma espécie de amolecimento rítmico que se imprime ao fraseado. Porém, essa similitude não se sustenta por muito tempo: enquanto Caymmi opta por manter a melodia espalhada, mantendo a melodia em tercinas até a palavra samba, Gilberto acelera a palavra morena, utilizando uma métrica baseada num grupo de sextinas. Temos aqui Gilberto optando por um caminho diferenciado, distanciando-se de Caymmi, mas esse aparte é momentâneo: já na palavra Samba a interpretação se conecta novamente.

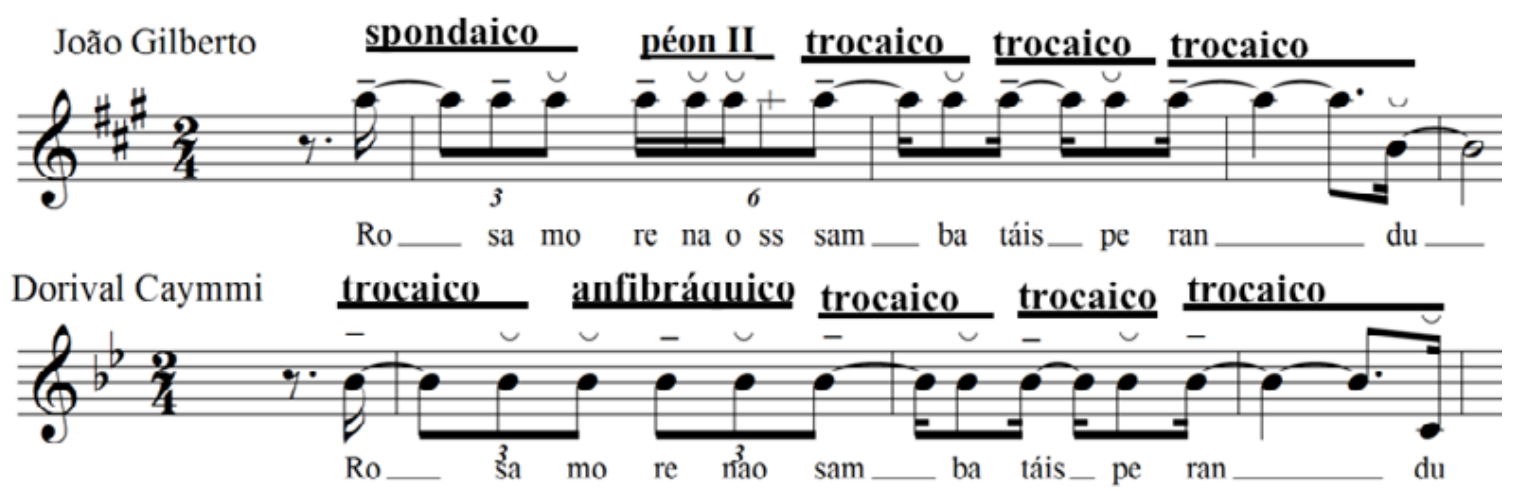

Exemplo 8. Rosa Morena. Comparação entre os pés-métricos utilizados por João Gilberto na seção A2 e Dorival Caymmi na seção B.

Temos, portanto, uma aproximação do fraseado de ambos, pelo menos na relação que se estabelece entre a interpretação de João Gilberto e o ritmo da melodia que caracterizaria o fraseado de Caymmi, mas esse encontro não ocorre no que diz respeito aos acentos que Gilberto imprime em sua interpretação. Sobre isso, deixemos o próprio Gilberto responder a essas questões:

Trata-se de algo que se trabalha a cada música. Se colocarmos o acento tônico sobre um mesmo tempo, fica chato. É preciso imaginar novas entonações para dar mais vida às palavras. (GARCIA, 1999, p. 128. O grifo é nosso).

Acreditamos que as escolhas de Gilberto serviriam para reorientar o ouvinte: essas modificações na condução melódica - que seriam flutuações da melodia sobre a harmonia- seria um procedimento calculado por João, buscando evitar a monotonia através da surpresa. Ao mesmo tempo em que ele mostra em sua interpretação os aspectos da composição original que para ele não estão no lugar correto. Ao interpretar a melodia utilizando um tipo de fraseado rítmico diferente da abordagem de Caymmi, Gilberto, ao contrabalancear essa tensão em sua opção pela manutenção dos acentos oriundos da interpretação feita por Caymmi, fortalece a nossa noção de desleitura, ou seja, o constante conflito da interpretação com a referência. Essa insistência também aponta para a busca pela manutenção de um tipo de tradição que é anterior ao estilo Bossa Nova. 


\section{IV}

As táticas musicais empreendidas por João Gilberto acabavam reforçando a conexão com elementos dessa mesma tradição. Dessa forma, além de aumentar seu capital simbólico e estabelecer ligações com elementos de peso dentro do que entendemos como campo, ela acabou alcançando, ao longo do tempo, posições mais elevadas na estrutura do Campo. Porém, ao mesmo tempo se questionavam um certo conjunto de procedimentos tradicionais. Assim, ao se embaralhar referências e mixar elementos musicais específicos, a Bossa Nova atinge um nível de formação identitário tão complexo que as conexões entre ela e os outros estilos - principalmente os que se inscrevem na chamada música popular brasileira - acabam se tornando extremamente conturbadas.

O conceito de campo é interessante por mostrar como as lutas entre os defensores de uma música genuinamente nacional e os modernos, que mixam elementos nacionais e estrangeiros. A partir da ótica de Bourdieu, podemos entender como esses agentes se movimentam no campo e como implementam ações estratégicas e táticas a partir dos lugares que ocupam na estrutura simbólica desse espaço. Se a estratégia é passiva e defensora da tradição que estrutura e confirma as posições de quem tem mais poder simbólico, a tática seria justamente o questionamento, a ação deformadora que pouco a pouco abre brechas no edifício estratégico e, mesmo sem a posse de um lugar, acaba imprimindo mudanças no campo. A vontade de manipular de forma diferente os bens simbólicos é que orienta a ação tática.

Acreditamos que a desleitura seja uma das chaves para se entender esse processo, pois ela possibilita a percepção de como uma influência é subvertida, remodelada e transformada a tal ponto que, ao invés de fazer brilhar a luz do original, o artista empreende uma contra força gravitacional tão grande que a única luz que chega aos olhos do público é oriunda não da referência, mas da obra do artista que transforma algo de outro em seu. Em resumo: ao mesmo tempo em que a desleitura age como uma tática de fortalecimento estilístico e também como uma ferramenta de legitimação dentro dos conflitos presentes no campo simbólico, ela enfraquece não apenas a identidade, mas o tipo de conexão com a tradição que se quer ligar.

João Gilberto desleituriza o samba, e nisso a Bossa Nova o acompanha, simultaneamente aceitando e rejeitando elementos oriundos de seus predecessores. Porém, essas operações receptivas não são organizadas de uma maneira tão simplória: o que é aceito sempre é transmudado, assim como aquilo que se rejeita eventualmente pode ser inserido e utilizado num outro ponto da mesma estética artística. Giddens (2012, p. 99) aponta que "há algo em relação à noção de tradição que pressupõe persistência; se é tradicional, uma crença ou prática tem uma integridade e continuidade que resiste ao contratempo da mudança". Seguindo essa premissa, a repetição dos padrões de uma tradição faz o futuro voltar ao passado, enquanto aproxima o passado para reconstruir o futuro. O que se descortina para eles é a idéia de que a tradição não é suficiente para dar certas respostas às perguntas fundamentais ${ }^{29}$. Tal situação cria uma angústia no 
indivíduo porque seria uma quebra entre o passado e o futuro, entre o espaço de experiência e o horizonte de expectativas ${ }^{30}$ e se estende para a sua obra artística.

João Gilberto teve uma relação muito próxima com uma série de posicionamentos estéticos oriundos de movimentos e estilos nem sempre concordantes e que sob a luz do projeto de desconstrução da tradição musical popular brasileira, eram entendidos como esforços insuficientes; porém, longe de descartá-los, ele estabeleceu uma relação indecisiva com eles ${ }^{31}$. É preciso apontar que isso não é uma negação simplória da influência, uma simples recusa com relação aos antecessores, é algo mais complexo: uma narrativa é construída e pautada em relações com o moderno ao mesmo tempo em que também se apega ao tradicional, embora lute para ultrapassá-lo - o exemplo máximo disso é a sua relação com a Caymmi.

Dito isso, temos que Gilberto se apropria de certos elementos interpretativos de Caymmi, mas ao mesmo tempo subvertendo o que lhe agrada e modificando o que lhe serve, a ponto de estabelecer uma conexão até com o que ele rejeita. Essa é uma atitude ao mesmo tempo ofensiva e defensiva: ofensiva por que, ao mesmo tempo em que se utiliza um artista forte como referência, perpetuando-o e estendendo sua temporalidade, se estabelece uma atitude de defesa, uma tentativa de afirmação que se inscreve durante e depois de se perceber à sombra de um gigante. Esse procedimento caracteriza a desleitura.

No campo da Física que estuda as particularidades das ondas, existe a noção de que duas perturbações ondulares em sobreposição podem se cancelar mutuamente. Ao atirarmos duas pedras sobre a superfície de um lago, cada uma delas criará um padrão circular que se espalhará, interferindo nas ondas geradas pela outra pedra. Basicamente dois extremos surgem: em alguns pontos as duas ondas se combinam para formar uma maior, numa interferência construtiva e em outros, uma onda cancela a outra, deixando aquele ponto imaculado, como se nada tivesse acontecido ali. Esse último caso forma o que os físicos das ondas chamam de interferência destrutiva.

Ao traduzirmos essas questões para o objeto de nosso estudo, percebemos que apesar dos esforços, a Bossa Nova de João Gilberto combina esses dois tipos de eventos: ao mesmo tempo construtiva, criando um novo estilo a partir de ondas oriundas de outros estilos e gêneros musicais, mas também ao mesmo tempo destrutiva, pois nesse ato antropofágico, acaba-se modificando não apenas o cenário artístico, mas imprime modificações nos estilos que lhe serviram de referência. É por essa fantasmagoria estética caracterizada pelo aceitar e rejeitar a tradição, e pelas táticas utilizadas em um espaço aonde a estratégia seria a opção mais coerente é que podemos dizer que a Bos-

\footnotetext{
pensamento: um modo de agir específico empreendido justamente quando os atores de um cenário tornam-se conscientes de que se movimentam em um intervalo de tempo totalmente determinado por coisas que não são mais e por coisas que não são ainda.

30 Para Koselleck (2006), o tempo histórico é ditado pela tensão entre expectativas e experiência sendo que na modernidade, as expectativas passam a distanciar-se cada vez mais das experiências feitas até então.

31 A expressão indecidíveis remete a um tipo de interpretação do que Derrida (1991) chama de operadores de leitura. É o caso do que ele chama de indecidivel, algo que não seria um conceito nem uma metáfora e que ao mesmo tempo em que apresenta uma ideia, a desapresenta. Apesar da impossibilidade de conectarmos o pensamento de Derrida com o de Bloom, devido as divergências com relação ao entendimento de uma obra estar no texto e no leitor de um texto, a utilização da expressão derridiana não comprometerá nossos argumentos sobre a questão da desleitura.
} 
sa Nova longe de ser amor, sorriso e flor se percebe sem paz e beleza, mas só tristeza e melancolia "que não sai de mim, não sai de mim, não sai".

\section{REFERÊNCIAS}

ALPERS, Svetlana. O projeto de Rembrandt: o ateliê e o mercado. São Paulo: Companhia das Letras, 2010.

ARAUJO, F.M., ALVES, E.M. \& CRUZ, M.P. Algumas reflexões sobre o conceito de campo e de "habitus". Revista Perspectivas da Ciência e Tecnologia: Rio de Janeiro, v.1, n.1, janjun, p. 31-40, 2009.

ARENDT, Hannah. Entre o Passado e o Futuro. São Paulo: Perspectiva, 2014.

BARROS, José D'Assunção. História Comparada. Petrópolis, RJ: VOZES, 2014. . Teoria da História. Petrópolis, RJ: Vozes, 2013.

BAUMAN, Z. Identidades. Rio de Janeiro: JZE, 2005.

BESSA, Virgínia de Almeida. A escuta singular de Pixinguinha: história e música popular no Brasil dos anos 1920 e 1930. São Paulo: Alameda, 2010.

BLOOM, Harold. A anatomia da influência: literatura como modo de vida. Rio de Janeiro: Objetiva, 2013.

Um mapa da desleitura. Rio de Janeiro: Objetiva, 2003.

. A angústia da influência: Uma teoria da poesia. Rio de Janeiro: Imago, 2002.

BOLLOS, Liliana Harb. Bossa Nova e crítica: polifonia de vozes na imprensa. São Paulo: Annablume; Rio de Janeiro: Funarte, 2010.

BOURDIEU, Pierre. A economia das trocas simbólicas. São Paulo: Perspectiva, 2013.

. As Regras da Arte: Gênese e estrutura do campo literário. São Paulo: Companhia das Letras, 1996.

. Os usos sociais da ciência: por uma sociologia clínica do campo científico. São

Paulo: Editora UNESP, 2004.

Questões de Sociologia. Rio de Janeiro: Marco Zero, 1983.

BUSCACIO, Gabriela Cordeiro. O campo artístico brasileiro na redemocratização polí- 
tica - MPB e Rock nacional. XXXVII Simpósio Nacional de História. Anpuh, Natal, 2013.

CASTRO, Ruy. Chega de Saudade: a história e as histórias da Bossa Nova. São Paulo: Companhia das Letras, 2008.

CAYMMI, Stella. Caymmi e a bossa nova: o portador inesperado (1938-1958). Rio de Janeiro: Ibis Libris, 2008.

. Dorival Caymmi: o mar e o tempo. São Paulo: Editora 34, 2012.

CERTEAU, Michel de. A invenção do cotidiano: 1. Artes de fazer. Petrópolis, RJ: Vozes, 2013.

COHEN, Sara. Polirritmos nos estudos para Piano de Gyorgy Ligeti (Primeiro Caderno). 2007. Tese (Doutorado em Música). Centro de Letras e Artes - Programa de Pós-graduação em Música.

COOPER, Grosvenor \& MEYER, Leonard. The rhythmic structure of music. Chicago: University of Chicago Press, 1963.

DERRIDA, Jacques. A farmácia de Platão. São Paulo: Iluminuras, 1991.

DINIZ, Edinha. A grande síntese. In: GARCIA, Walter (org). João Gilberto. São Paulo: Cosac Naify, p. 242-250, 2012.

DOMINGUES, André. Caymmi sem folclore. São Paulo: Editora Barcarolla, 2009.

FINNEGAN, Ruth. O que vem primeiro: o texto, a música ou a performance? In: MATOS, Claudia Neiva de, MEDEIROS, Fernanda Teixeira de \& TRAVASSOS, Elizabeth (orgs). Palavra cantada: ensaios sobre poesia, música e voz. Rio de Janeiro: 7Letras, p. 15-43, 2008.

GARCIA, Walter. Bim Bom: a contradição sem conflitos de João Gilberto. São Paulo: Paz e Terra, 1999.

(org). João Gilberto. São Paulo: Cosac Naify, 2012.

GAVA, José Estevam. A linguagem harmônica da Bossa Nova. São Paulo: Editora UNESP, 2002.

GIDDENS, Anthony. A vida em uma sociedade tradicional. In: BECK, Ulrich, GIDDENS, Anthony \& LASH, Scott. Modernização reflexiva: política, tradição e estética na ordem social moderna. São Paulo: Editora Unesp, p. 62-105, 212. 
GINZBURG, Carlo. O Queijo e os Vermes. São Paulo: Companhia das Letras, 1987.

Señales: Raíces de un Paradigma Indiciario. In: GARGANI, Aldo (org). Crisis de la Razón. México, p. 10-35, 1983.

GUSMÃO, Luis de. O fetichismo do conceito: limites do conhecimento teórico na investigação social. Rio de Janeiro: Top books, 2012.

HESSE, Hermann. Demian. Rio de Janeiro: Record, 2015.

JAUSS, Hans Robert. A História da Literatura como provocação à Teoria Literária. São Paulo: Ática, 1994.

JOBIM, Tom. Encontros. Organização e apresentação Frederico Coelho e Daniel Caetano. Rio de Janeiro: Beco do Azougue, 2011.

JOLY, Martine. Introdução à análise da imagem. Campinas, SP: Papirus, 2012.

KOSELLECK, R. Modernidade. In Futuro Passado - Contribuição à semântica dos tempos históricos. Rio de Janeiro: Contraponto, p. 267-303. 2006

LANA, Jonas Soares. Performance, invenção e subversão: reflexões sobre o uso dos conceitos de estratégia e tática de Michel Certeau no estudo da música. XXVII Reunião Brasileira de Antropologia. Pará. 2010. Disponível em: www.academia.edu. Acesso em 07/02/2016.

LERDAHL, Fred \& JACKENDOFF, Ray. A generative theory of tonal music. Cambridge: MIT Press, 1983.

LESTER, Joel. The Rhythms or tonal music. Carbondale and Edwardsville: Southern Illinois University Press, 1986.

LIMA, Denise Maria de oliveira. Campo de poder, segundo Pierre bourdieu. Revista Cogito. Salvador. n. 11, p. 14-19, outubro de 2010.

MATOS, Claudia Neiva de, MEDEIROS, Fernanda Teixeira de \&TRAVASSOS, Elizabeth (orgs). Palavra cantada: ensaios sobre poesia, música e voz. Rio de Janeiro: 7Letras, p. 15-43, 2008.

MATOS, Eliane Bragança de. A gênese da resistência criativa nas idéias de agência de Certeau e Habitus de Bourdieu. XXXV Encontro da ANPAD. Rio de Janeiro, 2011.

MEDAGLIA, Júlio. "Balanço da Bossa". In: CAMPOS, Augusto de. Balanço da Bossa e ou- 
tras bossas. São Paulo: Perspectiva, p. 67-124, 2008.

MELLO, Zuza Homem de. Eis aqui os bossa nova. São Paulo: Editora WMF Martins Fontes, 2008.

MENESCAL, Roberto. A renovação estética da Bossa Nova. In: DUARTE, Paulo Sérgio \&

NAVES, Santuza Cambraia. Do Samba-canção à Tropicália. Rio de Janeiro: Reluma Dumará: FAPERJ, p. 56-62, 2003.

MENEZES, Enrique Valarelli. A música tímida de João Gilberto. 2012. Dissertação (Mestrado em Música) - Escola de Comunicação e Artes: Programa de Pós-graduação em Música - Universidade e São Paulo.

MESSIAEN, Olivier. Traité de rythme, de couleur, et d'ornithologie. Paris: Alphonse Leduc, volume I, 1949-1992.

OLIVEIRA, Felipe Souza leão de. História e crítica literária: o caso Harold Bloom. XXVII simpósio nacional de história. Conhecimento histórico e diálogo social. XXXVII Simpósio Nacional de História.Anpuh, Natal, 2013.

OSTROWER, Fayga. Criatividade e processos de criação. Petrópolis: Vozes, 2013.

PEREIRA, Mateus H. De Faria \& SARTI, Flavia Medeiros. A leitura entre táticas e estratégias? Consumo cultural e práticas epistolares. ASPHE/FaE/UFPel, Pelotas, 2010. Disponível em: http://FAE.ufpel. Edu.br/asphe. Acessado em 01/02/2016.

PINTO, Júlio Pimentel. A leitura e seus lugares. São Paulo: Estação Liberdade, 2004.

REIS, Eliana Lourenço de Lima. Pós-colonialismo, identidade e mestiçagem cultural: a literatura de Wole Soyinka. Belo horizonte. Editora UFMG, 2011.

RISÉRIO, Antonio. Caymmi: Uma utopia de lugar. São Paulo: Perspectiva, 1993.

SCHOENBERG, Arnold. Fundamentos da composição musical. São Paulo: EDUSP, 2012.

SOUZA, Rodolfo Coelho de. Intertextualidade na música pós-moderna. In: SEKEFF, Maria de Lourdes \& ZAMPRONHA, Edson (orgs). Arte e Cultura V: estudos interdisciplinares. São Paulo: Anablume; Fapesp, p. 53-74, 2009.

TATIT, Luiz. O século da canção. Cotia: Ateliê Editorial, 2004.

TINHORÃO, José Ramos. Música popular: um tema em debate. São Paulo: Editora 34, 
2012.

TRIGO, Maria H. Bueno. Habitus, campo, estratégia: uma leitura de Bourdieu. Cadernos CERU. São Paulo. Série 2, n. 9, p. 45-55, 1998.

VELOSO, Caetano. Antropofagia. São Paulo: Penguin Classics Companhia das Letras, 2012. 